\title{
GENERAL FEATURES OF THE GOLD DEPOSITS IN THE RIO ITAPICURU GREENSTONE BELT (RIGB, NE BRAZIL), DISCUSSION OF THE ORIGIN, TIMING AND TECTONIC MODEL
}

\author{
FERNANDO CÉSAR ALVES DA SILVA*, ALAIN CHAUVET** \& MICHEL FAURE**
}

\begin{abstract}
RESUMO
FEIÇÕES GERAIS DOS DEPÓSITOS DE OURO DO GREENSTONE BELT RIO ITAPICURU (RIGB, NE DO BRASIL), DISCUSSÃO DA ORIGEM, IDADE E MODELO TECTÔNICO No greenstone belt do Rio Itapicuru (RIGB), importante concentraç̃̃es de ouro estão asssociadas a estreitas zonas de cisalhamento que afetam a sequiência supracrustal. Os trabalhos de mapeamento básico associados a geoquímica e geofísica levaram a descoberta de várias minas de ouro nesta região. Entre estas, a mina Fazenda Brasileiro é a maior delas com cerca de $140 \mathrm{t} \mathrm{Au}$. Neste trabalho procuramos mostrar o estado da arte, enfocando principalmente os aspectos gerais dos depósitos auríferos $\mathrm{e}$ a relação entre a mineralização e a evolução estrutural deste greenstone belt. A mineralização é essencialmente associada, direta ou indiretamente, com litologias carbonaceas e representada por veios e/ou vênulas de quartzo, ou disseminada em porções ricas em sulfeto, que definem os principais corpos de minério. Na principal mina o Au quase sempre ocorre relacionado a presença de arsenopirita, onde aparece como inclusões em microfraturas ou adsorvido nas fácies dos cristais deste mineral. As rochas hospedeiras da mineralização mostram claros efeitos de ação de eventos hidrotermais. Dados estruturais e geocronológicos recentes mostram que a precipitação do Au ocorreu tarde (2.083-2.031 Ga) aos principais eventos tectônico regionais $(c a$. 2.100-2.080 Ga). Uma combinação entre empurrões e os últimos estágios do magmatismo granítico podem ser responsável da geração dos fluidos mineralizantes. $\mathrm{O}$ Au lixiviado da pilha vulcânica, pelos fluidos metamórficos e àqueles relacionados aos plutons, migraram ao longo de anisotropias planar e linear pré-existentes. A migração destes fluidos dentro da zona de cisalhamento levou os corpos de minério a uma disposição onde seu eixo maior é paralelo a lineação de estiramento. O microfabric do quartzo e a orientação preferencial do seu eixo $<\mathrm{c}>$ indica que difusão-recristalização foi o principal mecanismo de deformação agindo nos veios de quartz auríferos. Este cenário explica as evidências metamórficas e magmáticas encontradas e utilizadas nas discusões sobre a origem da mineralização, bem como o ambíguo controle dos corpos de minério (os sulfetos se sobrepõe a foliação milonítica) pela lineação de estiramento.
\end{abstract}

Palavras-chave: Minas de ouro, eixo C do quatzo, greenstone belt do Rio Itapicuru.

ABSTRACT Anomalous concentration of gold is associated with relatively narrow shear zones in the supracrustal sequence of the Rio Itapicuru Greenstone Belt (RIGB). Both geological mapping and geochemical / geophysical surveys led to the discovery of several gold mines. Among them, the Fazenda Brasileiro mine (1401 Au) is the largest one. This paper draws the general features of the RIGB gold deposits and puts constraints on the relationship between mineralization and the structural evolution of the belt. Mineralization is essentially associated (direct or indirectly) with carbonaceous lithologies and is represented by quartz veins/veinlets thot define the main orebodies. In the main mines, Au is almost always related to the occurrence of arsenopyrite, appearing as inclusions, within microfractures or attached to the crystal faces. Hydrothermal effects have been recognized within the host-rocks. Recent structural and geochronological data show that gold precipitated late $(2,083-2,031 \mathrm{Ga})$ with respect to the regional tectonic events $(\mathrm{Ca}-2,100-2,080 \mathrm{Ga})$. A coupling between thrusting and late stage of granitic magmatism to account for the generation of the mineralizing fluids is suggested. By leaching Au from the volcanic pile, the metamorphic and pluton-related fluids were driven along early planar and linear anisotropies. Hence this pathway within the shear zones led to a geometric disposition of the oreshoots in which their long axes are parallel to the stretching lineation. Quartz microfabrics and <oaxis preferred orientation indicate diffusion-recrystallization as the main deformation mechanism acting in the Au-bearing quartz veins. This scenario explains the metamorphic and magmatic evidences for the origin of the mineralization as well as the ambiguous "control" of the orebodies (sulphides overprint the mylonitic foliation) by the stretching lineation.

Keywords: Rio Itapicuru greenstone belt, Shear zones, gold mines, Qz C-axis

INTRODUCTION A great part of the gold production in Brazil came from the São Francisco craton. Gold mainly occurs within volcano-sedimentary sequences such as those of the Quadrilátero Ferrífero, Jacobina and Rio Itapicuru, in the southern and north-eastern parts of the craton respectively (Fig. 1). The usually high potential of the greenstone sequences in hosting gold mineralization has led many mining companies to invest in exploration for precious metal deposits in these terrains. During the last decade, the discovery and exploitation of some mines and the delimitation of several targets have placed the Rio Itapicuru Greenstone Belt (RIGB) as an important locus for gold exploration. However, geologists still believe that the "great deposit" remains to be found.

The genesis of mesothermal Au-deposits has been the most controversial subject among any type of gold deposits and many aspects remain enigmatic. Several hypothesis have been proposed to account for gold origin, namely: metamorphic dehydration reactions (Boyle 1961), granulitization during the cratonization of mobile belts (Col vine 1989; Fyon et al 1989), fractional crystallization of felsic magma (e.g. Burrows and Spooner 1989) and circulation of meteoric water (Nesbitt and Muehlenbachs 1989). These models generally involve specific tectonic settings and many analogies have been drawn with modern plate-tectonic environments (Card et al. 1989; Hodgson and Hamilton 1989). Recently, the auriferous shear zone model has been largely applied, with relative success, to a lot of mesothermal deposits (Bonnemaison and Marcoux 1990). However, it may be stressed that auriferous shear zones essentially develop during the ductile-brittle to brittle stages of regional deformation. Thus, they are interpreted as late with respect to the regional tectonic evolution (e.g. Castaing et al 1993). In fact, the preferred structural setting of gold deposits is generally a second-order (ductile-)brittle subsidiary structures (e.g. Eisenlhor et al. 1989). Such a fact is sometimes inconsistent with the existence of a surprising parallelism between the long axes of ore- bodies and stretching lineations. This paradox still remains to be understood.

The purpose of this paper is to present a review of the RIGB auriferous districts, from the exploration phase (geochemical, geophysical and geological mapping) and mine development to the microstructural analysis. The results are essentially based on petrological, structural and metallogenic studies of gold-bearing quartz veins. As long axes of ore shoots frequently parallel the stretching lineation direction, the microtectonic analysis of the veins and the measurement of quartz c-axis preferred orientations enable some constraints on the deformation mechanism acting during vein emplacement. The origin of mineralizing fluids, the timing of formation of the mineralization, and the importance of ductile or brittle/ductile deformation stages in the control of ore shoots' geometry will be discussed.

\section{GEOLOGICAL FRAMEWORK OF THE RIGB In the Rio}

Itapicuru Greenstone Belt (RIGB), supracrustal units are exposed within an area more than $100 \mathrm{~km}$ long and about $60 \mathrm{~km}$ wide. The lithological succession of the low grade supracrustal pile consists, from bottom to top, of a tholeiitic volcanic unit, a calc-alkaline felsic volcanic unit and a sedimentary unit (Kishida and Riccio 1980). Geochemical and petrological arguments suggest a back-arc basin as the geotectonic environment for deposition of the supracrustals (Silva 1987). The supracrustal units are underlain by gneisses and migmatites considered as representative of the Archean basement (about 2,9 Ga, $\mathrm{U} / \mathrm{Pb}$ zircon, Gaál et al. 1987). Sequences are also intruded by several plurikilometre size granitoids dated around 2.0 to $2.2 \mathrm{Ga}$ and attributed to the Transamazonian cycle (Gaál et al. 1987). These intrusions produced contact metamorphism of the surrounding supracrustals (Matos and Davison 1987; Alves da Silva et al. 1993). The Transamazonian evolution of this region is linked with the closure of the "Greenstone basin", leading to the development of SE-directed thrusts (D1) coeval with earliest granite emplacement (Barrocas com-

Departamento de Geologia - Centro de Ciências Exatas e da Terra - Universidade Federal do Rio Grande do Norte (UFRN). Campus Universitário, Caixa Postal 1639, Natal, RN, CEP 59072-970 Phone: 084-215-3831, Fax: 084- 215-3806. -E-mail: fernando@geologia.ufrn.br

Département dês Sciences de Ia Terre, CNRS-URA 1366 and FR 09 , Université d'Orleans, BP 6759, F-45067 Orleans Cédex 2, France. 


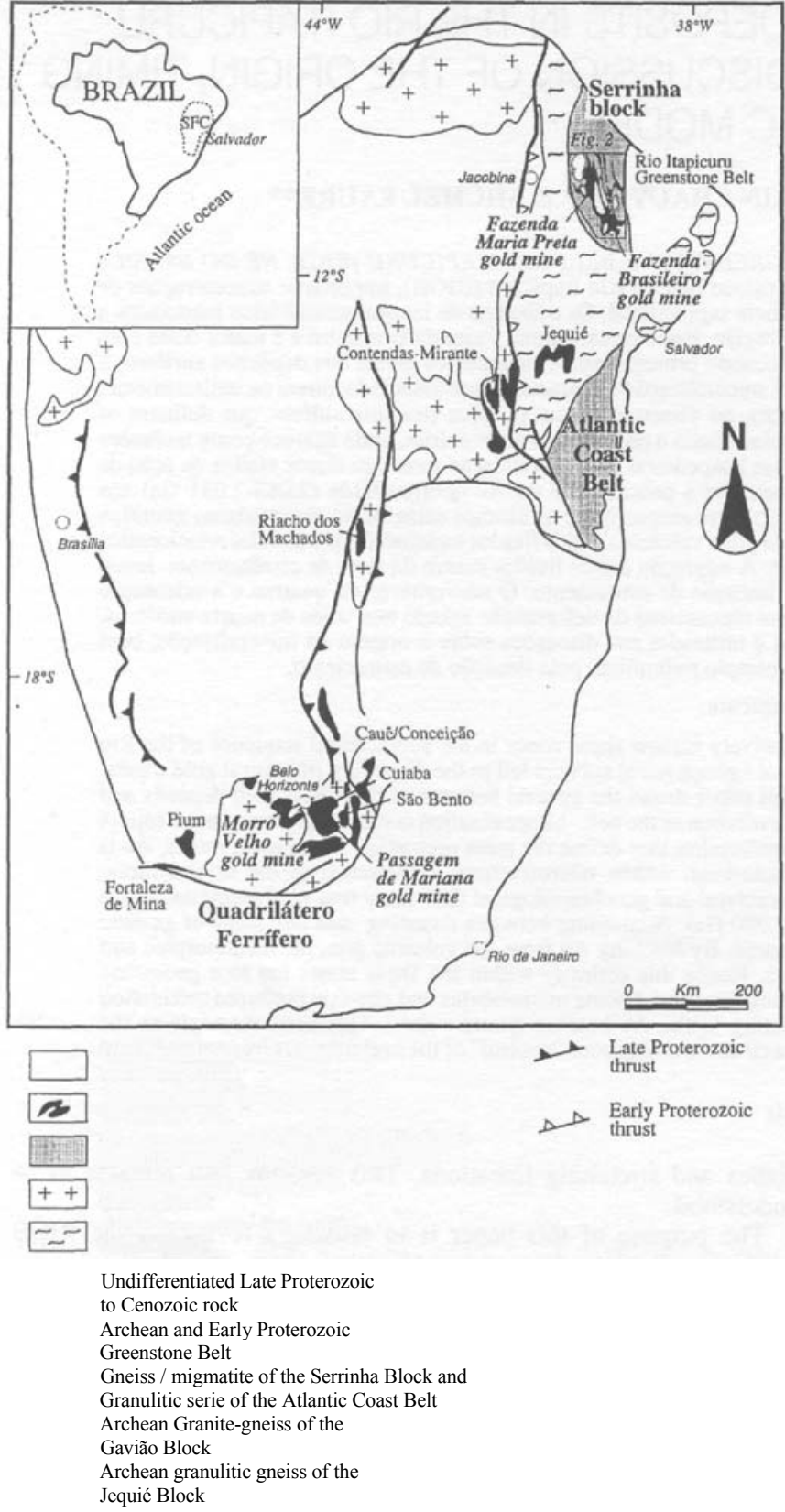

Figure 1 - Simplified map of the São Francisco Craton with Archean and Early Proterozoic domains and the main gold mines. The study area is located in the North-western part of the Craton (modified from Inda and Barbosa 1978; Bernasconi 1983).

plex)(Alves da Silva et al. 1995). The increase of the plutonic activity, as shown by the intrusion of the main plutons (i.e., Ambrósio, Pedra Alta, Efícéas and Nordestina, Fig. 2), is associated with a change of style of the deformation. The rising of the plutons led to the steeping of early-formed foliation planes and induced the development of left lateral strike-slip tectonics. This D2 event accounts for the overturning of the Weber belt and Barrocas complex in the south-eastern area (Alves da Silva et al. 1993; 1995).

The most important gold deposits are concentrated within two main zones herein named South Mineralized Zone (SMZ) and North Mineralized Zone (NMZ) (Fig. 2). The former corresponds to a group of 10 $\mathrm{km}$ long E-W striking shear zones, forming a large duplex structure (Kishida et al. 1991) along the southern domain of the RIGB (also named the Weber Belt, Fig. 3). This structure hosts several gold deposits known collectively as Fazenda Brasileiro mines. The $50 \mathrm{~km}$ long NMZ is characterized by bedding parallel N-S striking shear zones. The NMZ hosts $\mathrm{Ml}, \mathrm{Cl}$ and Antas mines and several targets that are economically less important than those of the SMZ.

DISCOVERY HISTORY Classical mineral exploration methods The main deposits were discovered by the DOCEGEO/CVRD company that carried out mineral exploration the region since 1972. The CBPM company participated in the discovery by prospecting alluvial gold along the Itapicuru river. A part of the data used in this paper was thus acquired by the senior author when he developed an exploration program for the DOCEGEO. In 1972, exploration was initially aimed at base metals at a very large regional scale. A great number of geochemical anomalies, including those of the volcano-sedimentary sequence of the RIGB, were detected. A systematic check of these anomalies was then initiated in 1974 and a year later, a finer scale (1 sample $\left./ \mathrm{km}^{2}\right)$ stream sediment geochemical exploration program was carried out. As a result, a large number of important base metal anomalies (mainly $\mathrm{Cu}$ and $\mathrm{Zn}$ ) was recognized. An aeromagnetic and electromagnetic survey by "INPUT" (Induced pulse transient) method was also carried out. Among the c.a. 2500 detected anomalies, 300 were chosen for field checking. Most of them appeared to result from graphitic material. However, a sample located within the anomaly $n^{\circ} 253$ area, described as a "quartz-feldspar breccia" with disseminated pyrite and arsenopyrite and containing $2 \mathrm{~g} / \mathrm{ton} \mathrm{Au}$, led to a change in mineral exploration in the region and the discovery of the Fazenda Brasileiro mine (SMZ). In 1980, a regional survey, at a scale of 1:100,000 was initiated in order to collect one sediment sample per $\mathrm{km}^{2}$ to count gold particles from pan concentrate and to carry out multi-element geochemistry. In the SMZ, this work, which revealed contents as high as 700 gold particles in soil samples $(\sim 5 \mathrm{~kg})$, were followed by a more detailed grid of soil sampling (variable up to $25 \mathrm{x}$ $25 \mathrm{~m}$ ). Geological mapping, trenching, drilling and shaft opening permitted the mineralization to be delineated precisely. Untill 1984, the work was mainly concentrated in the SMZ. In 1984, for the first time in Brazil, the method of heap-leaching was employed to extract gold from weathered ore in the Fazenda Brasileiro mine. In 1988, underground mining started. About $150 \mathrm{t} \mathrm{Au}$ was estimated down to the 160-level, although additional mineralization has been detected by drilling at $600 \mathrm{~m}$ depth.

Since 1984, 1:10,000 scale work started on the gold anomalies of the N-NW portion of the RIGB. Hence, 100 stream sediment samples per $\mathrm{km}^{2}$ were collected for gold counting in pan concentrate. As a result, an important group of anomalies was localized in an area immediately south of the Itapicuru river, named Antas. There, Au particle counting in soil was also developed along N-S trending topographic crests due to silicification. These procedures allowed the in situ position of the anomalies to be defined, which correspond with the three main targets Antas I, Antas II and Antas III. The exploration history and discovery of Antas I is representative of the development of the exploration phase for each mine. Au particle counting in soil was first carried out on a $100 \times 25 \mathrm{~m}$ sampling grid, rapidly restricted to a $25 \times 25 \mathrm{~m}$ area close to the main anomaly region. Later, multi-element soil geochemistry showed $A s$ to be a good pathfinder of gold and then confirmed the existence of the anomaly. During the following stages, these anomalies were evaluated by trench opening and chemical analysis of the bed-rocks. Complementary drilling defined the $3 \mathrm{D}$ shapes and allowed their economic evaluation. Four years after the beginning of this exploration phase, a minimum geological reserve (to $100 \mathrm{~m}$ depth) of about $12,5 \mathrm{t} \mathrm{Au}$ justified an initial investment for mining, whilst continuous research aimed to localize and evaluate new nearby anomalies.

\section{Correlation between Mineralization and Geophysics}

The geophysical methods, first applied to the discovery of the Fazenda Brasileiro gold deposits, were applied to the Antas area, after the recognition of the orebodies, in order to evaluate any relationships between geophysics and mineralization, radiometric and electromagnetic methods were used (Sena 1987, DOCEGEO internal report). The radiometric method measures the gamma-radiation (related to K-emissions) and the natural emission of $U+T h+K$. The application of this method must take into account that mineralization occurs in hydrothermally altered rocks that, theoretically, could be enriched or depleted in these elements. The electromagnetic method defines zones of maximum conductivity. In the southern part of the RIGB, this method has demonstrated that the greatest anomalies are related to graphitic layers, but the relations with gold mineralization were never clearly established.

The radiometric and electromagnetic methods produce coherent results for Antas I (NMZ), illustrated by excellent correlations between anomalies, conductive zones and localization of the orebodies. For Antas III, there exists a weak difference between these anomalies and the known orebodies. Similarly, the Antas III mineralization does not occur inside, but between two conductive zones. The Antas II deposit does not present a good correlation with the geophysical data. Orebodies do not correspond to the higher radiometric values. Such a fact suggests the existence of a more complex pattern for the Antas II deposit compared to Antas I and III. This is confirmed by this study.

As result of this comparison between geophysical data and orebody localization, we can suggest the existence of a more or less valid connection between conductive rocks, radiometric anomalies and mineralization. However, it would be necessary to proceed to further 


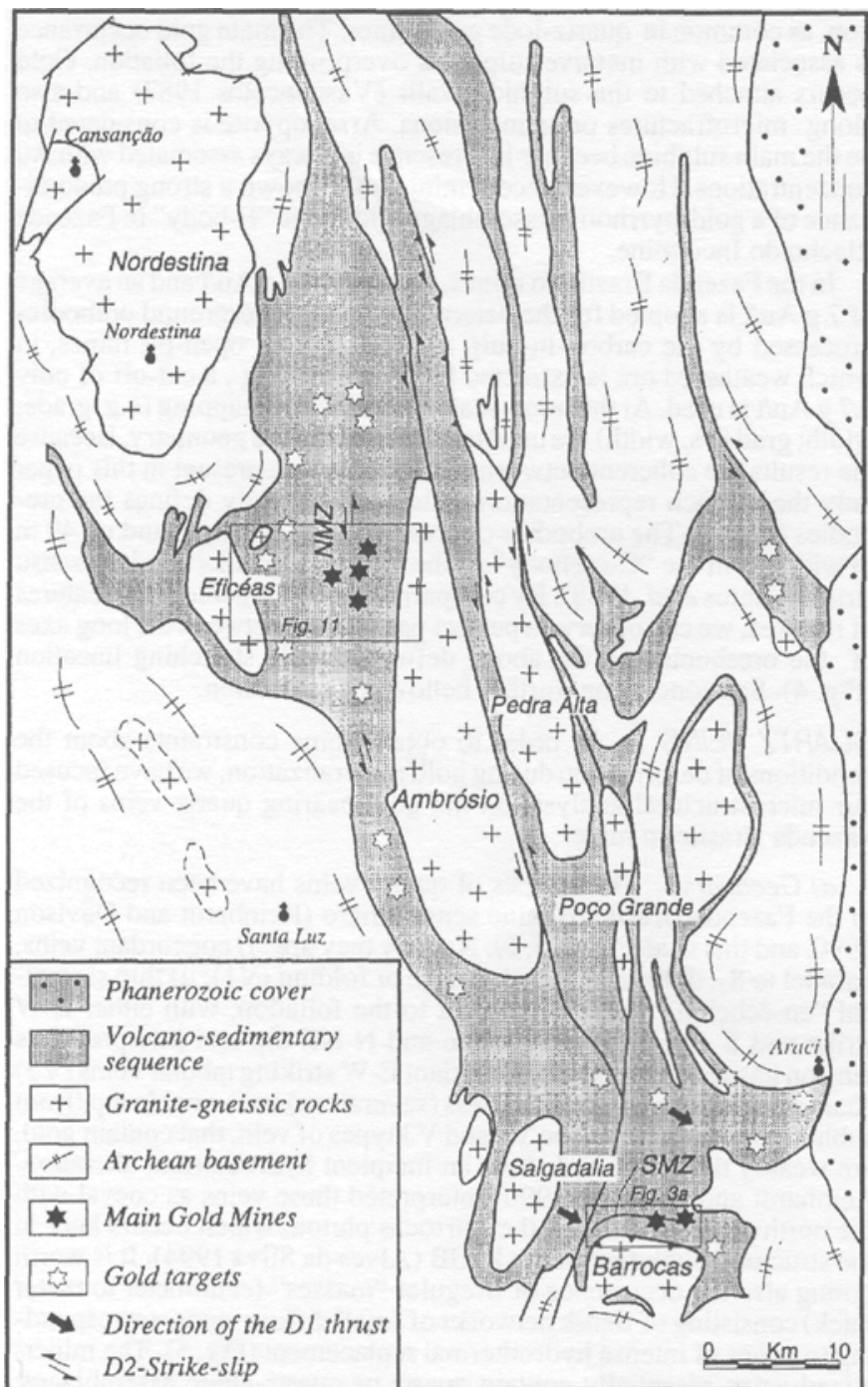

Figure 2 - Simplified geological map of the Rio Itapicuru Greenstone belt. The North Mineralized Zone (NMZ) and South Mineralized Zone (SMZ) are indicated. The name of the main granites referred in the text is also marked.

complementary measurements before concluding that electromagnetic and radiometric methods can be used systematically for gold exploration in other parts of the belt.

\section{THE SOUTH MINERALIZED ZONE (SMZ) AND ITS GOLD}

MINES The Weber Belt The Weber belt, located in the southern part of the RIGB (Fig. 2), hosts the most important gold concentrations in the region. Seven mines, referred to as "Fazenda Brasileiro Gold Mines", are found from east to west (Fig. 3a): Canto II, Canto I, Fazenda Brasileiro, Riacho do Incó, Dor de Dente Este, Dor de Dente and Pau-a-Pique. Canto I and II mines do not belong to the same lithological unit as the others cited above. The best-known and most important mine of the area is Fazenda Brasileiro itself.

The foliation in the Weber belt trends east-west with a high-angle southwards dip (Fig. 3b). The present E-W orientation of this belt was successively interpreted as being acquired during a late (post-granite emplacement) macrofold (Alves da Silva and Matos 1991) or contemporaneous with the main granite emplacement event (D2, Alves da Silva et al 1993). The geometry of the numerous vertical faults affecting this belt (Fig. 3a) has been interpreted as a compressive duplex initiated in a horizontal position and later rotated into the subvertical (Kishida et al. 1991). In a recent study, it has been proposed that foliation in the Weber Belt was formed during an earlier SE-verging thrusting event (Dl) and overturned during the main D2 event (Alves da Silva 1994). In such a case, the lithological units that compose the Weber belt are structurally overturned. Thus, from south to north, and from bottom to top, can be distinguished four units (Santos et al. 1988; Vitorasso et al. 1991, mine terminology will be given in parentheses)

(1) The Incó unit, which is mainly composed of carbonate-chlorite schist (CCX) with minor intercalations of carbonaceous schist lenses. The protolith of this rock is assumed to be basaltic lava.

(2) The Fazenda Brasileiro unit, which is dominated by felsic and mafic schists. Containing the most important gold concentrations, this unit needs to be described in more detail (Fig. 3b). Three internal sequences are identified, i) The Graphitic schist (GRX), which forms the hanging wall of the main ore zone. Due to its lateral persistence and distinctive character, it is considered as a guide horizon, ii) The Iron-rich quartz-chlorite schist (CLX), which corresponds to two major layers of 20 and $3 \mathrm{~m}$ average thickness (Fig. 3b). Part of this unit situated at the contact with the GRX hosts the main ore shoot. A detailed discussion about its origin will be presented below, iii) The "Intermediate Sequence", which is composed of sericite-chlorite-carbonate schist (CAX) and plagioclase-actinolite schist (PAX). The latter are weakly altered gabbroic bodies which show ophitic to subophitic textures and which occur disseminated within the CAX and sometimes within the CLX (Fig. 3b). The CAX rocks represent less mafic surrounding basalts.

According to Teixeira (1985) and Teixeira et al. (1990), the Fazenda Brasileiro unit as a whole would represent a mafic sill, emplaced between metabasalts and turbidites; the intrusion being differentiated into metagabbro (PAX and CAX), grading to metaferrogabbro (CLX), and even into metaanorthosite (quartz-feldspatic breccia) at the top. Such a pattern appears inconsistent with the reverse dip of the unit. An alternative interpretation suggests that the gabbro (sensu stricto) was restricted to the PAX lithologies (Alves da Silva and Matos 1990, CVRD company internal report) and that the CLX consisted of differentiated tholeiitic basalts (see discussion below).

(3) The Canto unit, which consists of fine-grained carbonaceous sediments (pelites and rhythmically banded pelites and psammites), volcanic layers and an agglomeratic pyroclastic sequence. The pyroclastic sequence is the main host rock for the mineralization (Alves da Silva 1990).

(4) The Abóbora unit, which is located in the northernmost part of the Weber Belt (not represented on Fig. 3b). It comprises a thick sequence of basalt flows with local and narrow sedimentary intercalations. The Abóbora gold occurrence (not represented in Fig. 3a) is the only one hosted in this unit (Kishida et al. 1991).

Because of their lithological similarities, both the Incó and Abóbora units are integrated within the basal mafic unit. A controversy still exists about the stratigraphic position of the Canto unit. If we consider that the Canto unit is a part of the upper sedimentary sequence, its position within the core of the basal unit remains difficult to explain. Indeed, it appears satisfying to suggest that the Canto unit is a particular fades of the intermediate or even basal unit.

DISCUSSION OF THE ORIGIN OF THE CLX LAYER The origin of the CLX layer, the part of the Fazenda Brasileiro unit that contains the main ore concentration, needs to be discussed for a better understanding of the $\mathrm{Au}$ mineralization. Based on field, petrological and geochemical arguments, the CLX layer has been successively interpreted as Banded Iron Formation (Monte Lopes 1982), quartz-porphyry (Vial 1986, CVRD Company, internal report), meta-ferrogabbro (Teixeira 1985; Teixeira et al. 1990) or metagraywacke (Melo Jr. 1990). The first and fourth interpretations involve a sedimentary origin, whereas the others argue for igneous sources.

The CLX has also been interpreted as a differentiated tholeiitic basalt (Alves da Silva and Matos 1990, CVRD company internal report). When they are in contact, relationships between the CLX and CCX layers (part of the Incó unit) support the interpretation that the first (CLX) results from tholeiitic differentiation of the latter (CCX). Moreover, the increase of the $\mathrm{Fe}$ content, the decrease of the $\mathrm{Cr} \mathrm{O}_{2}$ and $\mathrm{TiO}_{2}$ content and the increase in free quartz are very common features of residual tholeiitic magmas (Teixeira, 1985). Thus, the CLX will be herein considered as a differentiated product, formed at the end of the tholeiitic basalt volcanism, with two distinct stages of crystallization: (i) in the magma chamber, where porphyries of quartz, plagioclase and magnetite are formad; and (ii) during the extrusion stage. Where the aphanitic matrix is formed. This seems to be in agreements with Teixeira et al. (1990) statements which suggestes that Petrological evolution of the intrusion shows a trend of iron enrichment.

Gold mines of the Fazenda Brasileiro unit MINE STRUCTURE In mine areas, a bedding parallel foliation is the earliest 

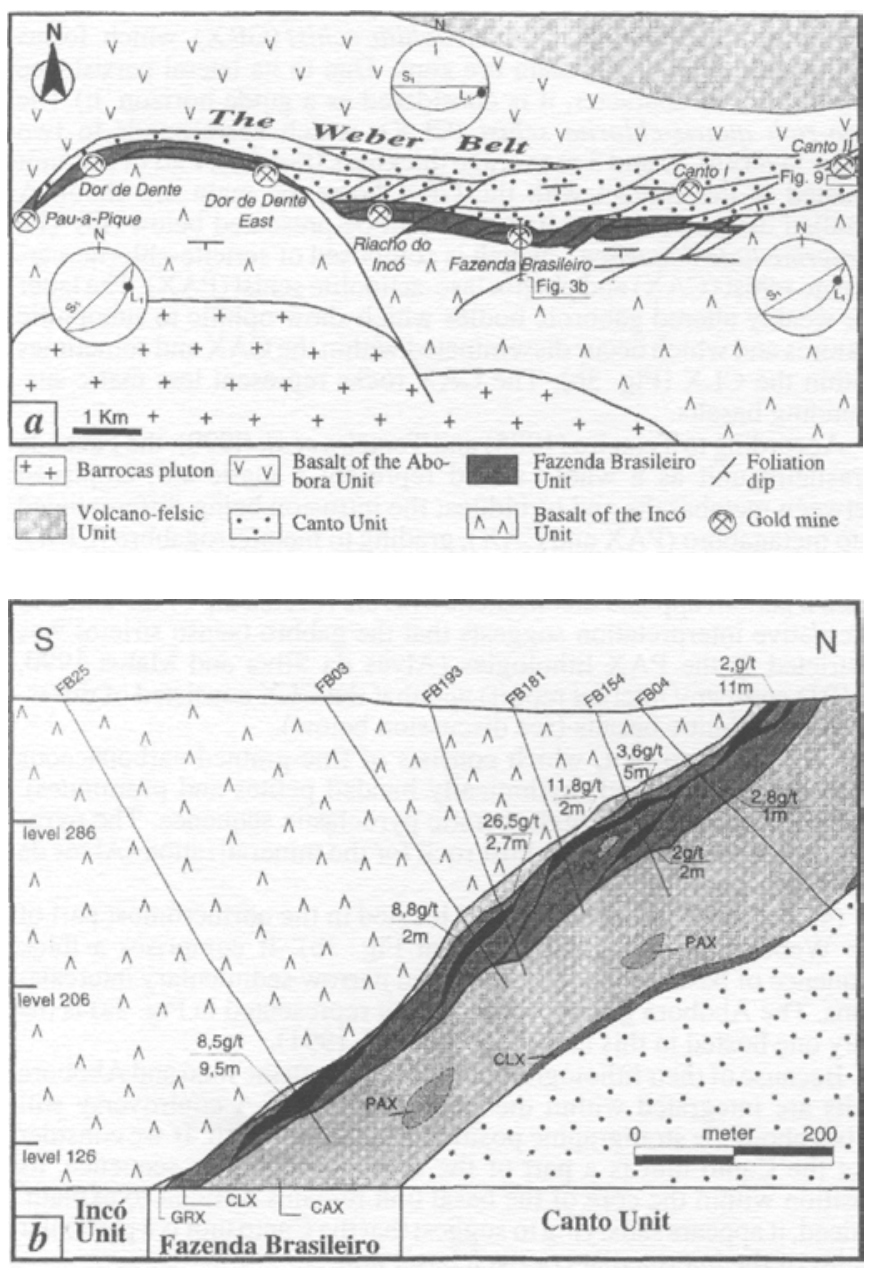

Figure 3 - a. - Detailed geological map of the South Mineralized Zone with gold mines referred in the text (modifiedfrom Kishida et al. 1991). Lower hemisphere, Schmidt stereonets represent the varying attitude of the foliation and stretching lineation across the Weber Belt. b. North-south cross-section of the Fazenda Brasileiro deposit (modified from CVRD company internal report). Note that mineralization (in black) is concentrated within the CLX level. Au-content and orebody thickness are marked for each bore-hole. The level number expresses the height with respect to the sea level.

recognized deformation structure (Teixeira 1985; Reinhardt and Davison 1990). The foliation, representative of the main shearing planes (Kishida et al. 1991), is assumed to have developed in a horizontal position during a top-to-the SE Dl thrusting event (Alves da Silva et al. 1993). Elongated minerals and quartz rods define a subhorizontal stretching lineation that can present higher dipping values in the western Weber Belt (see the stereonets, Fig. 3a). Kinematic analysis within the mine areas and their vicinity, points to a general ductile dextral shearing, which in fact corresponds to the overturned top-tothe-SE Dl shear criteria. Numerous vertical NE-SW faults that define the "duplex" geometry (Fig. 3a) and affect the imbrication of the main gold-bearing rocks, are also attributed to the Dl event. These faults, which are favorable sites for fluid flow, were latter re-used during the more brittle event and ore concentration.

ORE DESCRIPTION The orebodies consist of sets of centimeter to meter scale quartz veins with variable amounts of sulphides (pyrite, arsenopyrite, pyrrhotite). Gold appears freely with an erratic distribution, as common in quartz-lode gold mines. The main gold occurrence is associated with massive sulphides overprinting the foliation. Gold occurs attached to the sulphide walls (Vasconcelos 1987) and also along microfractures or as inclusions. Arsenopyrite is considered to be the main sulphide because its presence is always associated with $\mathrm{Au}$ concentrations. However, recent mining has shown a strong predominance of a gold-pyrrhotite assemblage within the "E-body" in Fazenda Riacho do Incó mine.

In the Fazenda Brasileiro mines, a cut-off of $3 \mathrm{~g} \mathrm{Au} / \mathrm{t}$ and an average of $7 \mathrm{~g} \mathrm{Au} / \mathrm{t}$ is adopted for the determination of underground orebodies processed by the carbon-in-pulp method. Within open-pit mines, in which weathered ore is extracted by heap-leaching, a cut-off of only $0.7 \mathrm{~g} \mathrm{Au} / \mathrm{t}$ is used. At the mine-scale, few kinds of mapping (e.g. grade; width; grade vs. width) are used to constrain the ore geometry. Because the results are coherent between all the maps, we present in this paper only the isopach representation which satisfactorily defines the orebodies (Fig. 4). The orebodies can reach $500 \mathrm{~m}$ in lenght and up $40 \mathrm{~m}$ in width as in the "C-orebody" of the Fazenda Brasileiro mine (sensu stricto, Santos et al. 1988). By comparison with the geological features of the area, we can observe a perfect parallelism between the long axes of the oreshoots and the above defined ductile stretching lineation (Fig. 4). See conclusion further bellow for discussion.

QUARTZ VEINS In order to obtain some constraints about the conditions of deformation during gold mineralization, we have focused our microstructural analysis on the gold-bearing quartz veins of the Fazenda Brasileiro mine.

a) Geometry Three types of quartz veins have been recognized in the Fazenda Brasileiro mine sensu stricto (Reinhardt and Davison 1990, and this study, Figs. 5,6). Namely they are: i) concordant veins, parallel to $\mathrm{S}_{1 \text { : }}$ deformed by boudinage or folding (VI); ii) thin sigmoidal "en-échelon" veins, discordant to the foliation, with either E-W strike and S dip, or W-NW strike and N-NE dip and interpreted as tension gashes (V2) and iii) discordant E-W striking tabular veins (V3) characterized by a greater thickness (several $\mathrm{cm}$ ) and variable dip (from subhorizontal to $60^{\circ} \mathrm{S}$ ). The V2 and V3 types of vein, that contain gold, are weakly deformed and show an incipient hydrothermal alteration. Reinhardt and Davison (1990) interpreted these veins as coeval with the northward thrusting of the Barrocas pluton, which occurs later in the structural evolution of the RIGB (Alves da Silva 1994). It is worth noting also the occurrence of irregular "masses" (centimeter to meter thick) consisting of dense networks of small diffuse veins, corresponding to zones of intense hydrothermal replacement (Fig. 5). The mineralized veins essentially contain quartz or quartz-albite assemblages. The associated sulphides, when present, are systematically localized along their margins.

MICROFABRICS Vein filling is usually massive, although banded structures, witness of multi-stage fracture-infill can be found. The texture of the quartz grains indicates that brittle-ductile deformation occurred, controlled by two distinct mechanisms: "Cataclasis" that effected the intra-grain fracturing along which quartz recrystallization concentrates and subordinate "crystal plasticity", marked by the initiation of intracrystalline deformation features expressed by undulose extinction, sub-grain development and deformation bands (Figs. 7a, b).

Concordant veins (VI) are the most deformed. Fluctuation in the rate of dynamic recrystallization is recorded all along the Weber belt. Polygonal structure with typical $120^{\circ}$ contact was found in NE dipping veins of the western portion (Fig. 7c, location A on Fig. 8). The two types of discordant veins (V2 and V3) showing abundant quartz phenoclasts ( $2 \mathrm{~mm}$ in size on average) just showing undulatory extinction, deformation bands, lamellae and sub-grain development (Figs. $7 \mathrm{a}, \mathrm{b})$. The phenoclasts are affected by the development of elongate subgrains. The occurrence of serrated boundaries characterizes the occurence of a grain boundary migration mechanism (Fig. 7b). The initiation of new grain formation is shown by the scarce presence of very small size quartz grains along the margins of relict quartz grains. As new grains and subgrains present different crystallographic orientations with respect to the relict host (Fig. 7a), we suggest that a continuous sub-grain rotation recrystallization process operated (White 1977, Drury and Urai 1990).

QUARTZ C-AXIS PREFERRED ORIENTATION Quartz C-axes were measured in different points of the Weber belt mines (Fig. 8). Westward, the analyzed samples have been collected in the Pau-aPique (location A, FB-04) and Incó (location B, FB-02) mines, within 
ten centimeters width foliation parallel quartz veins. Within the Fazenda Brasileiro mine (sensu stricto), a quartz vein (GI-78) and its host rocks ( $\mathrm{FBa}$ and $\mathrm{FBb}$ ), coming from the highly mineralized CLX level, were selected. Measurements were made using a standard universal stage and in all samples the measurements were done in the $\mathrm{XZ}$ plane of the strain ellipsoid.

Sample FB-04 shows a diagram characterized by $<\mathrm{c}>$ axes concentrated along the $\mathrm{XY}$ plane, with a point maximum close to the $\mathrm{Y}$ axis (Fig. 8a). Sample FB-2 shows a type I crossed girdle with the development of maxima between the $\mathrm{X}$ and $\mathrm{Z}$ axes (Fig. 8b). For sample GI-78, the $<\mathrm{c}>$ axis maximum lies in the ZY plane at an intermediate position between both axes (Fig. 8c). The CLX sample is characterized by the presence of blue quartz-eyes. Measurements were made in both porphyroclasts (Fig. 8d) and recrystallized grains (Fig. 8c)! The porphyroclasts show a less oriented pattern with the development of three maxima, two of them close to $Z$ while the weaker maximum is near the $\mathrm{X}$ axis. $<\mathrm{c}>$ axis distribution of the recrystallized grains is marked by the presence of a submaximum near $\mathrm{Y}$ axis and a slight obliquity defined by point maxima position.

INTERPRETATION As a whole, the quartz $\mathrm{C}$-axis preferred orientation does not shown well defined asymmetry and no clear kinematic informations can be inferred. Moreover, quartz diagrams do not show evidences for high temperature deformation (Fig. 8). This fact is consistent with temperatures obtained by fluid inclusion analysis developed on the Fazenda Brasileiro gold-bearing quartz $\left(370-420^{\circ} \mathrm{C}\right.$ Xavier 1993). Concerning the texture, the large variation observed along the Weber belt suggests that recrystallized grains were the result of dynamic recrystallization rather than annealing. Combining the fact that there is no evidence for high temperature and no clear preferred orientation of $<\mathrm{c}>$ axes, it is likely that dynamic recrystallization was promoted by the presence of a diffusion-enhancing fluid film along the grain-boundary (Drury and Urai 1990). Moreover, the coexistence between recrystallized quartz grains and intergranular / transgranular microfractures, sealed by carbonates and phyllosilicates, indicates the transition from crystal-plasticity to fracturing that is dominated by diffusion and fluid mechanisms (solution precipitation creep and grainscale dilatation, Cox and Etheridge 1989). Indeed, quartz $<\mathrm{c}>$ axis orientation is interpreted not to result exclusively from intracrystalline slip deformation but to be strongly influenced by fluid-assisted recovery processes (Gleason et al. 1993; Jessell 1988; Jessell and Lister 1990). Such process dominates at low temperature because diffusion rate is too slow for dislocation climb to be efficient (regime 1 of Hirth and Tullis 1992). PT conditions in which such regime would be expected are near the brittle-ductile transition. This confirms that gold-bearing quartz veins took place during the later ductile-brittle to brittle stages of the deformation (Chauvet et al. 19,91).

HYDRO THERMAL ALTERATION Hydrothermal alteration, developed around the mineralized quartz veins, is traduced by gray leached aspect and general coarser texture, contrasting with the dark-green colour and finer grain size of the host rock. The size, width and even existence of this halo is controlled by host-rock chemistry and vein orientation. When veins are parallel to the foliation, the halo is regular and symmetric. When veins are, even slightly, oblique to the foliation, fluid percolation gives an irregular dentate aspect to this halo. Scarcely, when quartz-veins extend out of the CLX toward the adjacent CAX, the halo is not observed (Santos et al 1988). Detailed study of the hydrothermal halo (Marimon et al 1986) show the decrease of chlorite and quartz associated to the increase of carbonate, albite, opaque and biotite towards the vein. The variation of selected chemical elements also help to the definition of the main hydrothermalized Au-bearing rocks of the Weber belt as has been illustrated by Melo Jr. (1990) and Kishidaeia/. (1991).

The Fazenda Canto mines GEOLOGY Two gold deposits, Canto I and Canto II, are explored within the Canto unit. Due to its reverse position, this EW to NE-SW trending sequence dips toward the south and appears under the mafic Fazenda Brasileiro sequence (Figs. 3a, b). For a long time, the host rocks were described as "feldspar-sericite-quartz schist" and "feldspar-sericite-chlorite-quartz schist". Presently, the protolith is interpreted as a pyroclastic sequence that shows a continuous gradation, due to an increase of the matrix amount, from agglomerates (northern part) to tuffs (southern part)(Alves da Silva 1990). Within the mineralized zones, metasediments and subordinate dacites are rather limited because agglomerates host the main orebodies. In these rocks, tephras, mineralogically similar to the matrix, have very fine texture and are composed of chlorite and plagioclase.
DEFORMATION Although the deformation history of the Canto mines area is poorly studied, the same structural evolution proposed above for the Fazenda Brasileiro area is adopted here. However, some differences are recorded mainly due to the more ductile Theological behavior of the Canto unit lithologies. Foliation planes and lineation were represented on stereonet diagrams for the Canto II mines (Fig. 9). Quartz rods, boudinaged quartz vein and the alignment of the micaceous minerals define the stretching lineation that presents a constant shallow dip towards the E-NE (see the stereonets, Fig. 9). Preliminary estimates of the bulk strain in this zone (Alves da Silva 1990), obtained by the $\mathrm{Rf} /<()$ method (Ramsay 1967) applied on the agglomerate pebbles reveal values of strain ratio (Rs) varying from 16 to 25 (see also Alves da Silva 1991a). Stretching along the major principal axis (X axis) attained $163 \%$ whereas shortening reached $60 \%$ following $\mathrm{Z}$ axis. The strain ellipsoid changed from apparent flattening shape in the outer part of the shear zone to apparent constriction one in the inner part. Kinematic indicators (e.g., foliation sigmoidal patterns, drag folds and pressure shadows around porphyroclasts) indicate everywhere a dextral shearing (Fig. 7d) herein correlated to the Dl tectonics (Alves da Silva 1994).

MINERALIZATION If gold appears systematically associated with Fe-rich lithologies within the Fazenda Brasileiro mines, its occurs differently at Canto where quartz veins parallel or sub-parallel to the mylonitic foliation contain the main mineralization (Fig. 7d). They are interpreted as shear veins (Hodgson 1989) and can measure ten meters long and a few meters wide. Oblique and normal veins with respect to the foliation are small and subordinated. Orebodies are also defined by host rocks injected by a great number of quartz veinlets. The orebody contours, using a cut-off of $0,7 \mathrm{~g} \mathrm{Au} / \mathrm{t}$, demonstrates that they are elongated E-W, roughly parallel to the ductile lineation (Fig. 9).

Gold-bearing sulphides like the arsenopyrite are less important than in the Fazenda Brasileiro mines. The emplacement of mineralized quartz veins induced hydrothermalism within the host rocks that is characterized by growth of albite, sericite, carbonate, sphene, chlorite and scarce sulphides (pyrite and arsenopyrite). In fact, it appears that the gold concentration in the Canto mine was realized by the injection of quartz-rich fluid during the late stages of the ductile deformation without a strong control by the Fe-rich lithologies like for the Fazenda Brasileiro mines. In this place, the role played by iron-rich layer in gold mineralization seems then less important whereas the rate of deformation looks more crucial.

\section{THE NORTH MINERALIZED ZONE (NMZ) AND ITS GOLD}

MINES The NMZ rocks show a monotonous geometry characterized by a N-S trending and westward high-angle dipping foliation. The three main volcano-sedimentary units above described (the basal tholeiite, intermediate felsic and upper sediment) are also represented in this area (Fig. 10). Four main gold mines (C I, Antas I, Antas II and Antas III mines) occur in this area (Fig. 10). C I, Antas I and HI are located along the lithological contact between the intermediate and upper supracrustal units whereas Antas II occurs within the intermediate sequence, frequently associated to the presence of minor lenses of upper sedimentary unit (Figs. 10,11).

Lithological description The three main sequences are described in the following section. More details are given for litholologies that contain gold mineralization. Local name is given in parentheses.

a) The basal mafic sequence (the Rebolo Unit) occurs western of the studied area and comprises massive to schistose tholeiitic basalts sometimes showing pillow structure. The occurrence of interlayered mafic tuffs, flow breccias, chemical sediments and phyllites can be observed.

b) The intermediate felsic sequence (the Maria Preta Unit) is represented by andesitic lavas with intercalations of pyroclastic lenses and metasediments. The andesite constitutes the footwall rocks of Antas I, Antas HI and CI mines and is the dominant host-lithology of the Antas II mine (Figs. 10, 11). The fresh rock is compact, grayishgreenish coloured, fine grained, and shows a blasto-porphyritic texture. It is composed of euhedral phenoclasts of plagioclase that occurred within a matrix mainly constituted by small-size plagioclase, carbonate, chlorite, biotite, sericite, and quartz.

c) The upper sedimentary sequence (The Riacho Sêco Unit) is a complex succession of quartz-chlorite-sericite schist, graywacke, conglomerate, quartz-carbpnaceous-schist and tuff. Schists, that derived of carbonaceous material, are the dominant lithology and often consist in the hanging wall of the gold-bearing zones. Here also, the relation between gold and carbonaceous material (i.e. graphitic schists within 


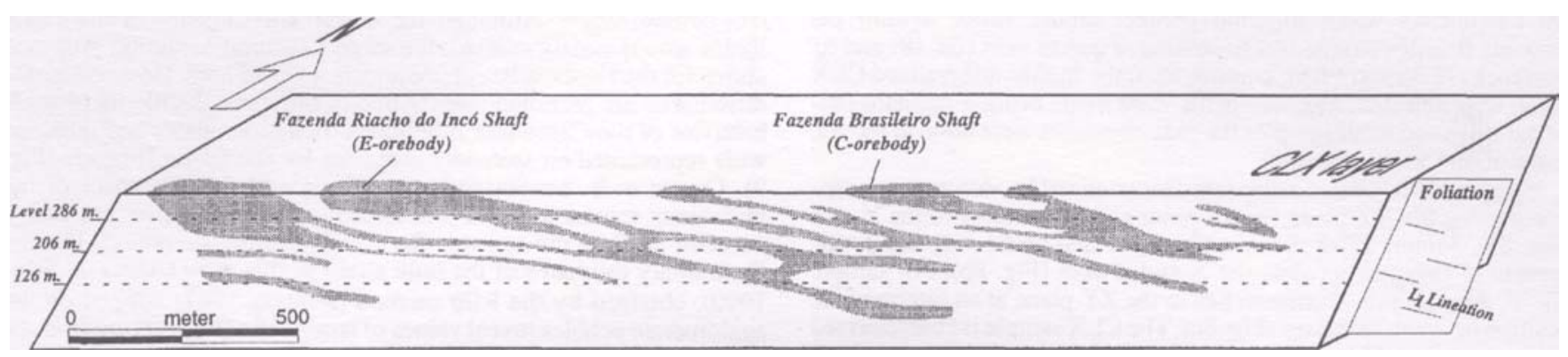

Figure 4 - Block-diagram of the disposition of oreshoots defined by isopachs, Fazenda Brasileiro (C-orebody) and Fazenda Riacho do Incó (E-orebody) gold mines. Note that the orebodies are apparently parallel to the ductile stretching lineation. The level number expresses the height with respect to the sea level.

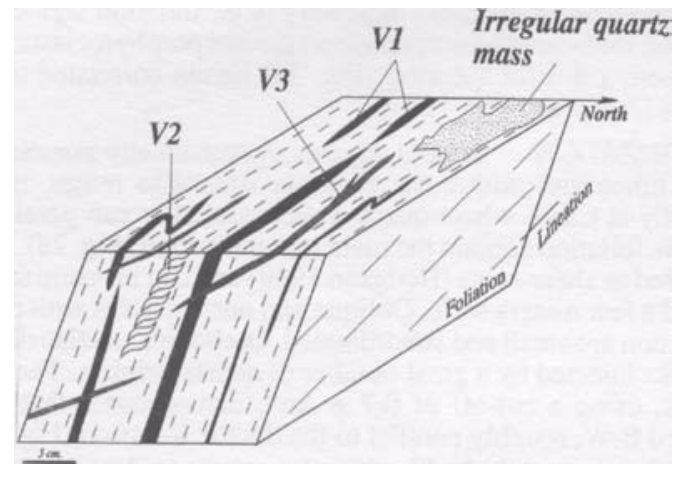

Figure 5 - Synthetic block diagram that summarize the geometric pattern of quartz veins within the Fazenda Brasileiro mines.

the Fazenda Brasileiro mine) is clearly established. Meta-graywackes form narrow levels that show granolepidoblastic texture and are composed by sericite, biotite, quartz, plagioclase, rock fragments and opaque minerals. The meta-graywackes sometimes grade into coarser epiclastic conglomerates characterized by felsic to intermediate volcanic pebbles dispersed within a matrix composed of carbonate, white mica, quartz, chlorite, scarce pyrite and hematite. Preserved sedimentary structures such as cross bedding can be observed.

Dacitic and dioritic bodies frequently intrude the intermediate and upper sequences. Dacites are abundant within Antas I and Antas III mines. They present a blasto-porphyritic texture with quartz and plagioclase porphyroclasts immersed into a matrix composed of small idiomorphic plagioclase, sericite, carbonate, quartz and opaque. Sericite in the matrix is generally oriented, giving a weak schistosity to the rocks. The medium grain diorite occurs under the form of large-size foliated bodies (Fig. 10) composed by euhedral plagioclase with blasto-intergranular texture where chlorite replaces original mafic minerals.

Mine Structures This part of the RIGB was dominated by the left-lateral ductile shearing (Fig. 11) associated to the emplacement of the main granites and attributed to the second tectonic event (D2 event, Alves da Silva et al, 1993, Alves da Silva 1994). The main gold deposits are included with four shear zones (fig. 10) that have been mainly defined on the basis of deformation analysis across prospecting trenches. From the economic point, the "shear zone 1"(SZ-1) and "shear zone 2" (SZ-2) are the most important (fig. 10) (alves da Silva and Matos, 1987). Antas I, Antas III and C-1 mines are hosted by the shear zone 1, whereas Antas II is located along the shear zone-2.

STUDIES OF THE SHEAR ZONE 1 Within the SZ-1, a stretching lineation with average direction and dip close to $355 / 25$ and $335 / 30$ for Antas I/C I and Antas III mines respectively can be recognized. Such a lineation is attributed to the D2 left-lateral shearing. Compressive duplex structures, defined by the imbrication of the meta-sediment/meta-dacite units (Kishida et al. 1991), have been described within the mines area. These structures, difficult to observe, are herein interpreted as relicts of the $\mathrm{Dl}$ tectonics.

The widespread occurrence, in the open pits, of breccias, cataclasites and brittle to brittle-ductile faults clearly indicate the importance of the brittle deformation (Chauvet et al. 1991), probably due to hydraulic failure related to high fluid pressure (see the below discussion on the hydrothermal effects). In Antas I, faults are oriented N040,

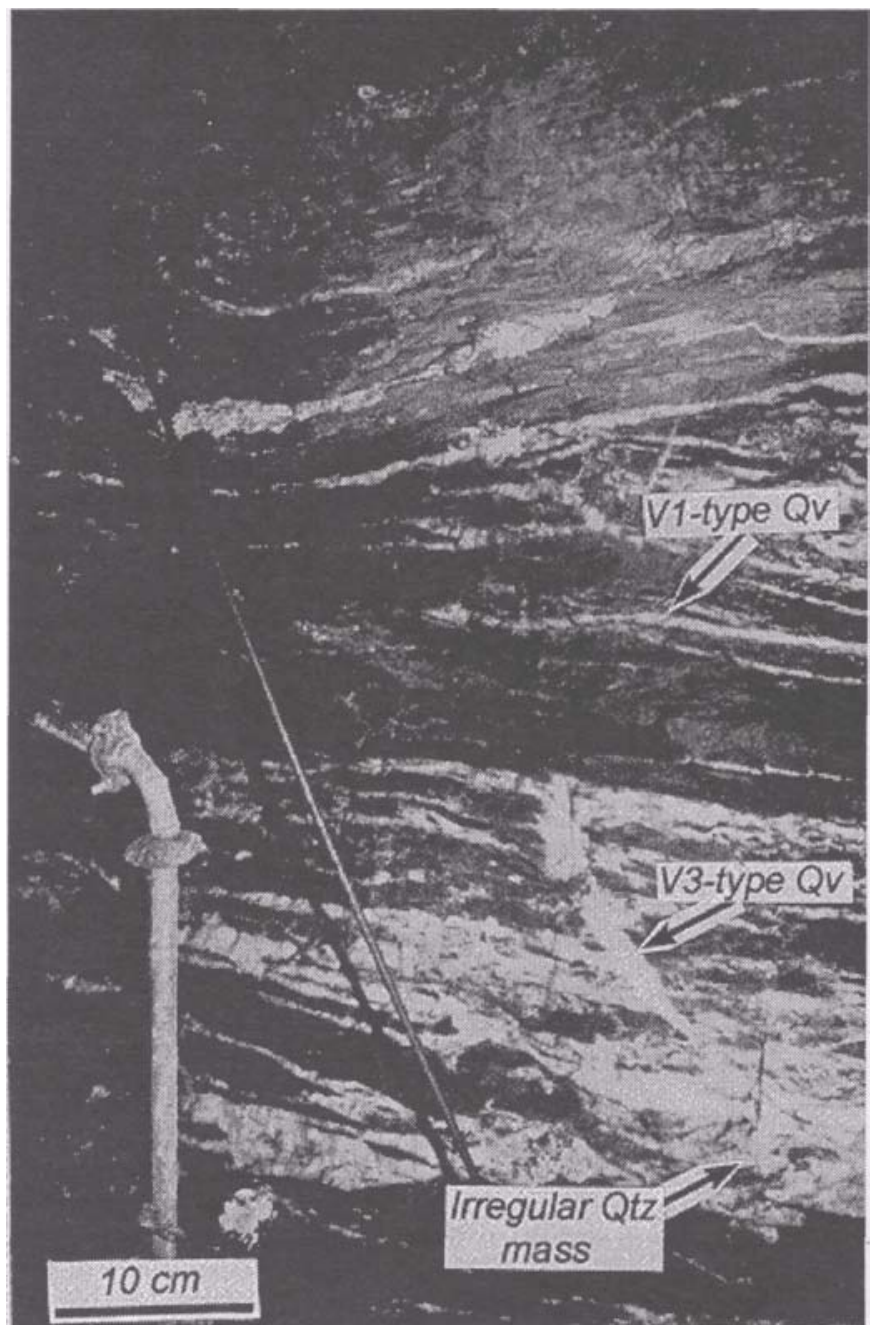

Figure 6 - General attitude of the gold-bearing quartz veins in the Fazenda Brasileiro gold mine. Note the existence of quartz vein parallel and oblique with respect to the foliation. Qv - quartz vein.

N-S and N120 (mine internal maps and Oliveira, pers. com., Fig. 11). The two former families re-use pre-existent discontinuities and concentrate the mineralization. Fracture analysis from trenches and drill cores demonstrates that normal faulting predominates.

STUDIES OF THE SHEAR ZONE 2 As a result of the less competent behavior of the rocks, the deformation style within the SZ-2 is marked by a more ductile character than in the SZ-1. The development of folds from open to sheath geometry can occur. The structuration becomes more complex from south to north. Toward the north, the lineation, marked by quartz rods, exhibits a strongly dispersed orientation. Southward, lineation presents a constant dip with an average value of $335 / 35$. This direction is also that of the mineralized bodies, thus provided a good field guide for prospecting (Oliveira et al. 1988, 

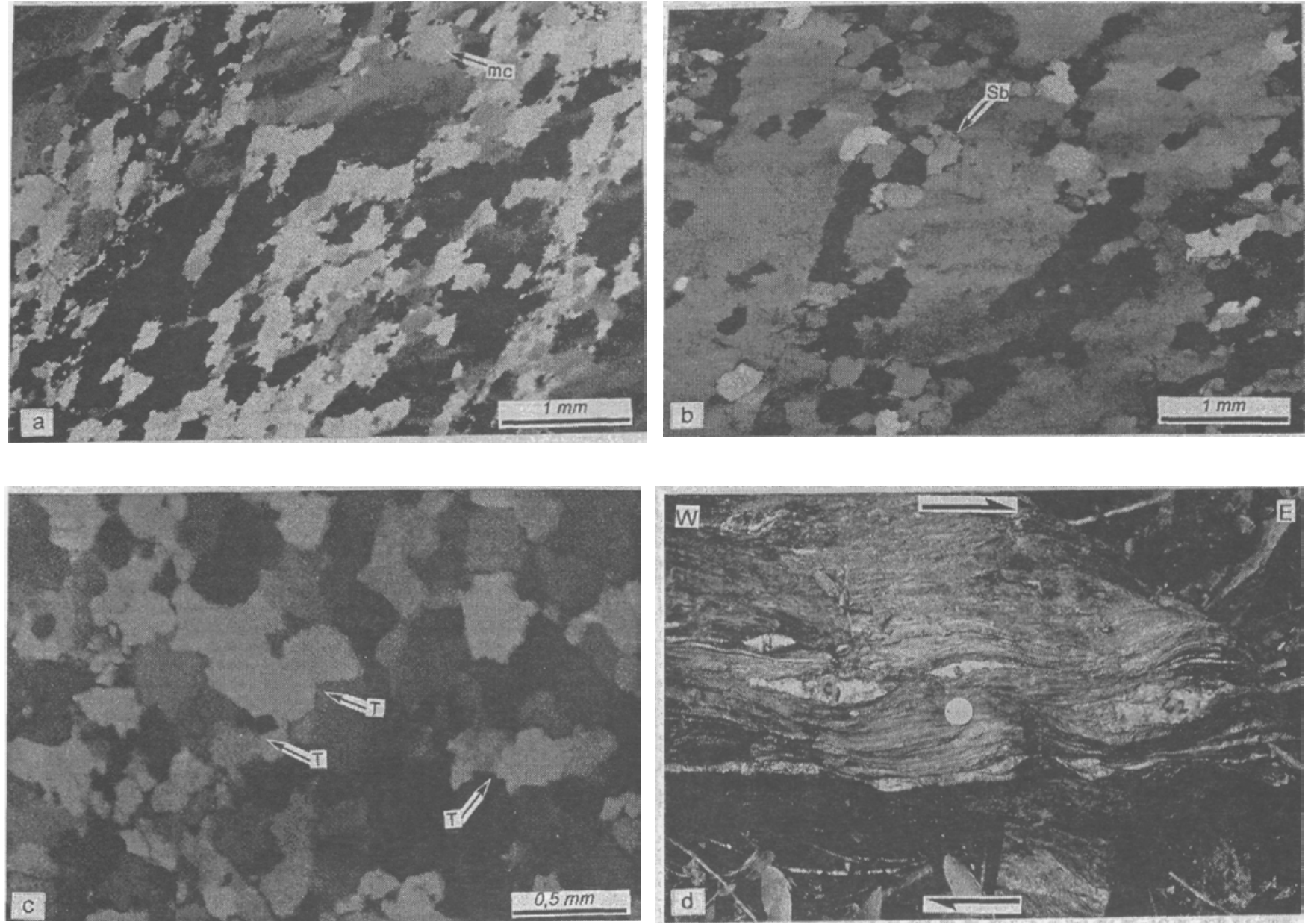

Figure 7 - a, b.- Microscopic aspect of quartz vein within the Fazenda Brasileiro mine showing uncompleted low-temperature dynamic recrystallization. Note the persistence ofrelictual large-size grains and the appearance of small-size new grains, me = mantle-core structure, $\mathrm{Sb}=$ Serrated boundary, c.- Microscopic aspect of quartz vein within the western portion of the Weber belt in which polygonal quartz reflect higher temperature conditions of deformation and recrystallization. Arrows indicate the location of triple point contact (T). d.- Boudinaged quartz vein at Canto II mine indicator of a dextral sense of shearing.

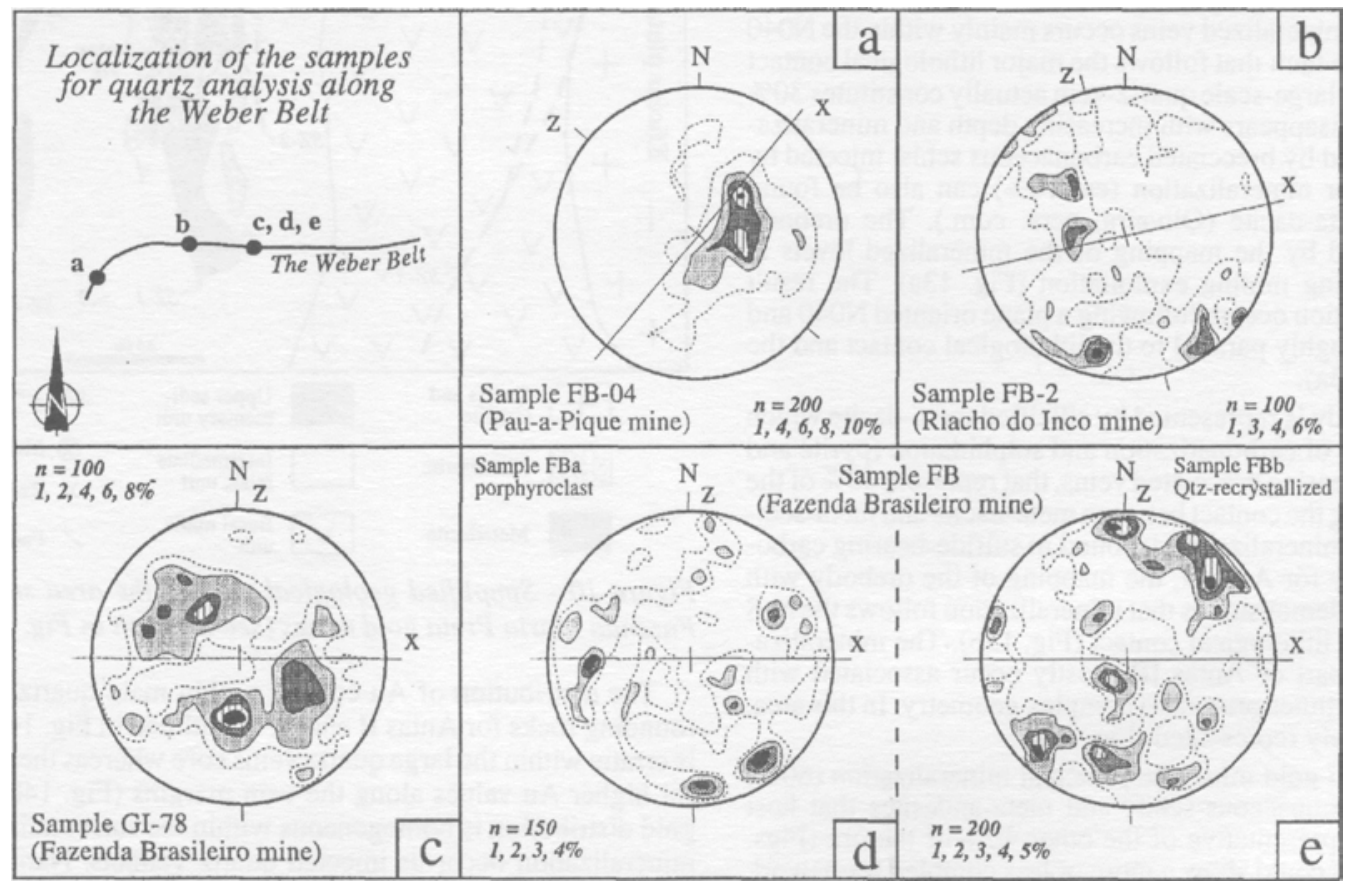

Figure 8 - Cry stallo graphic fabrics of quartz axes for selected samples of the Weber belt. Sample locations, numbers of grains measured and contour values are indicated. Diagram are Schmidt, lower-hemisphere, stereonets. In each diagram, the equator line (indicator of the foliation plane) has been oriented with respect to the north. See text for comments. 


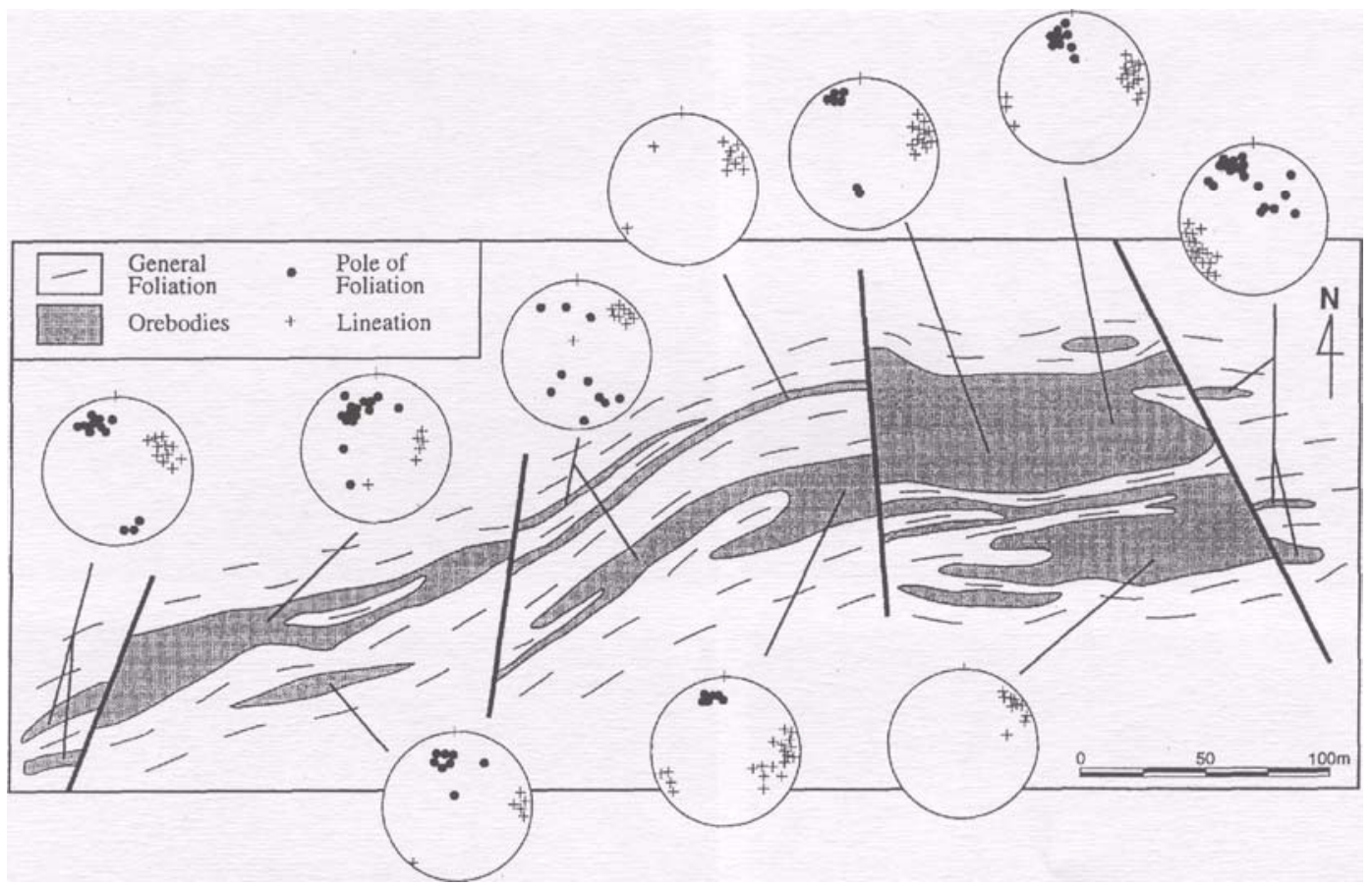

Figure 9 - General orientation oforebodies within the Canto II mine with respect to the foliation and lineation that are indicated into Schmidt, lower-hemisphere, stereonets (modified from Alves da Silva 1991a).

DOCEGEO Company Internal report; Vial 1986, CVRD company internal report).

Ore description Within the mines of the northern domain, mineralization is essentially represented by quartz vein. They occur following three types of geometry: i) vein parallel or oblique to the foliation (Fig. 12a); ii) complex arrangement that define a typical stockwork (Fig. lib, c); and iii) fine injected veinlets that give a silicified aspect to the host lithology. The veins consist essentially in massive quartz and rare sulphides. The vein thickness ranges from few $\mathrm{cm}$ to $2 \mathrm{~m}$.

Because they are localized along the same lithological contact, Antas I and Antas III present similar pattern that strongly differs from the more complex Antas II deposit (Fig. 11).

In Antas I/C I, the mineralized veins occurs mainly within the N040 trending brittle-ductile fault that follows the major lithological contact (Fig. 11). In surface, a large-scale quartz-vein actually constitutes $30 \%$ of the ore. This vein disappears with increasing depth and mineralization is then represented by brecciated carbonaceous schist injected by quartz veinlets. Minor mineralization (ca. 10\%) can also be found within brecciated meta-dacite (Oliveira, pers. com.). The orebody geometry is estimated by the mapping of the mineralized levels at different altitude during mining exploitation (Fig. 13a). The result shows that mineralization occurs following a plane oriented N040 and dipping westward, roughly parallel to the lithological contact and the main foliation (Fig. 13a).

In Antas III, orebody is represented by silicified meta-dacite which also shows the effects of carbonatization and sulphidation (pyrite and arsenopyrite). Gold-bearing brecciated veins, that represent $40 \%$ of the ore, also develop along the contact between meta-dacite and meta-sediments. Subordinated mineralization is found in sulfide-bearing carbonaceous schist. Likely for Antas I, the mapping of the orebody with respect to the altitude demonstrates that mineralization follows the N-S trending foliation and lithological contact (Fig. 13b). The mineralization in the southern part of Antas III mostly occur associated with quartz veins that sometimes presents a complex geometry. In this area, meta-diorites are largely represented (Fig. 10).

Within the Antas II gold mine, the principal mineralization (60\%) is represented by carbonaceous-schist and meta-andesites that host larger quartz veins representative of the other $40 \%$ of the ore (Figs. $12 \mathrm{a}, 13 \mathrm{c}$ ). These veins could show a more or less complex framework (Figs. 14b, c, d, e) that became extremely confuse towards the north (Fig. 14f). The schist and andesite appear like silicified and brecciated zones intruded by a swarm of mineralized quartz veinlets.

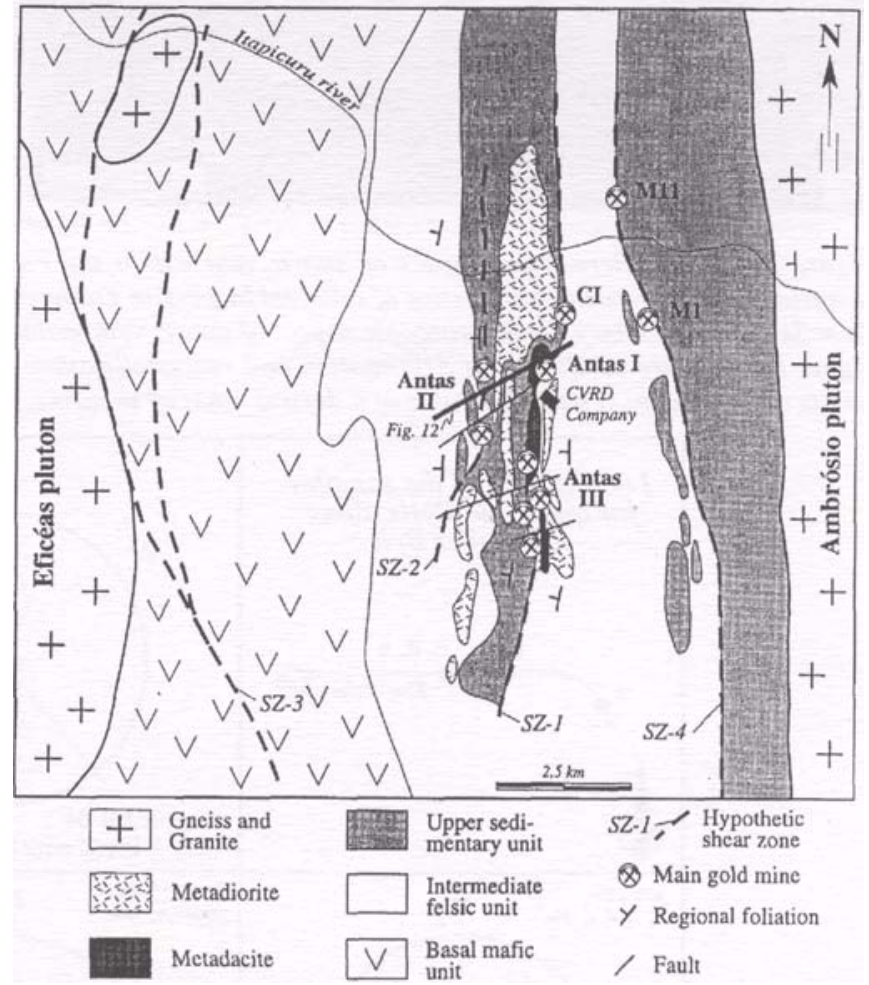

Figure 10 - Simplified geological map of the area surrounding the Fazenda Maria Preta gold mines (see location in Fig. 2).

The distribution of $\mathrm{Au}$ content within main quartz veins and surrounding rocks for Antas II and III is outlined in Fig. 14. Gold content is erratic within the large quartz veins core whereas there is a tendency for higher Au values along the vein margins (Fig. 14b). Conversely, gold distribution is homogeneous within the surrounding rocks where mineralization occur as injected quartz veinlets. Native gold is also found freely under the form of 0.1 to $0.8 \mathrm{~mm}$ flakes within quartz veins or filling microfractures. Because of the lack of mineralization within the large quartz vein core, we can highlight the important role played 


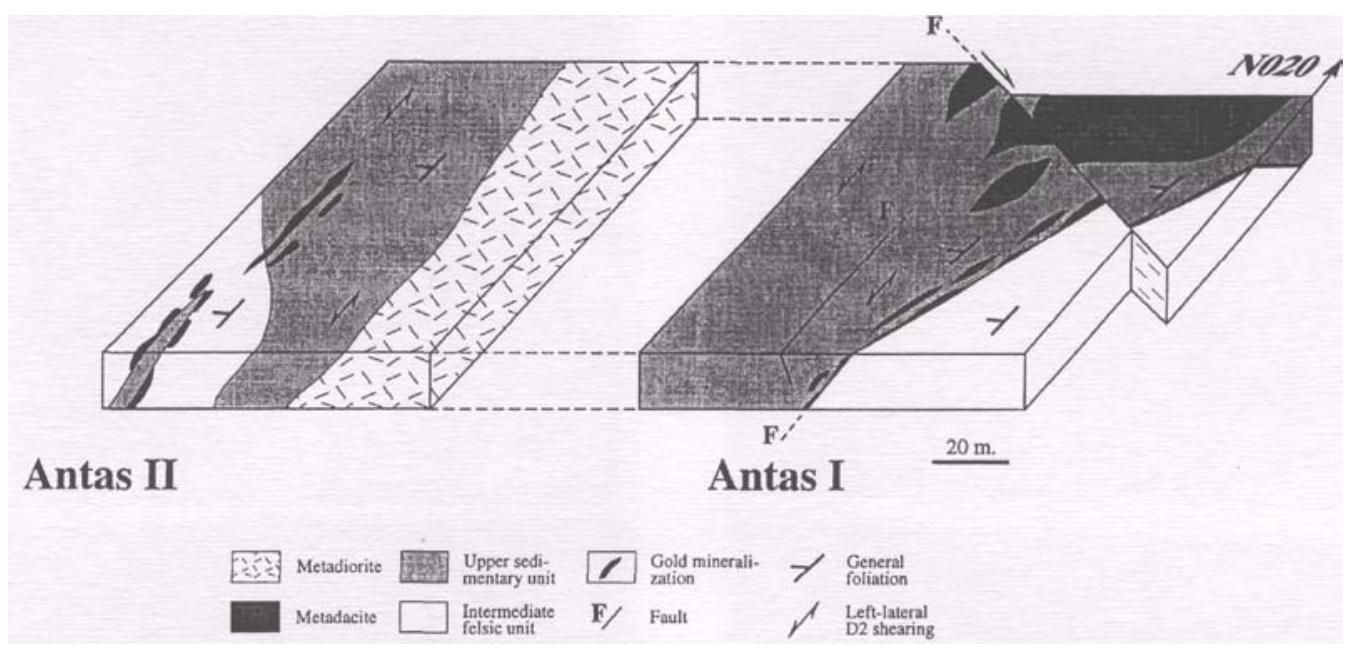

Figure 11 - Interpretative block diagram illustrating the main geological and structural feature s of the Antas I and Antas II gold deposits. Note that Antas III, which is localized along the similar lithological contact, occurs under similar conditions to those of Antas I

by the interaction between fluid and wall-rocks in the gold precipitation process. Within the host-rocks, gold is also associated with sulphides (pyrite, arsenopyrite, pyrrhotite) and occurs as inclusions along grain boundaries, microfractures or attached to the crystal faces.

Although they present a N-S elongated pattern, the orebodies have a long axis which frequently dips toward the north, roughly parallel to the stretching lineation as illustrated in the schematic block-diagram (Fig. 15). However, if orebodies plunge parallel to the stretching lineation, the parallelism appears to be less marked than in the SMZ.

Quartz veins GEOMETRY Tentative classification of the quartz-veins of the Maria Preta gold mines has been proposed (Coelho 1994). However, the complexity of the vein pattern, as illustrated by different detailed maps of the mines (Fig. 14), does not allow us to divide the veins using the classical nomenclature of "shear" and "extension" veins (Hodgson 1989).

Most of the veins are appoximately parallel to the regional foliation. In a detailed study, Neves (1991) has shown that $75 \%$ of the veins occur subparallel to the foliation (maximum angle of $10^{\circ}$ between vein and foliation) with $22 \%$ strictly parallel. The veins trend NNW-SSE or NNE-SSW, dip toward the west (Fig. 14a), and measure a few centimeters in length and width. The largest can reach $25-30 \mathrm{~m}$ in length and $1.0-2.5 \mathrm{~m}$ in width (Fig. 14). Other economically important veins trend E-W (Figs. 14a, b, c). They are particularly well-developed within competent lithology such as dacite, diorite and gabbro (Antas III) and in Antas II. Except in Antas II where they are similar to the foliation-parallel veins (Figs. 14a, b), these veins are largely subordinated in abundance, size, width and gold content. It appears that, with rare exceptions (Fig. 14c), even E-W oriented veins are systematically parallel to the foliation that presents some inflexions perhaps due to late normal faulting (Figs. 14a, b, d). Within zones of extreme complexity for the foliation geometry, like north Antas II domain, a similar complex pattern is observed for the veins (Fig. 14f).

The occurrence of brecciated zones is also observed within mine areas and argues for an active cataclasic process. "Breccia-vein" type results of the inclusion of broken and angular fragments of the wall rocks within a quartz-vein. Stockwork pattern is represented by quartz vein invasion and important silicification of the dacitic lithologies of Antas III and Antas I (Figs. 12b, c; respectively).

MICROFABRICS Within the veins, euhedral to subhedral quartz grains occur as large phenocrysts showing undulose extinction, variable degrees of deformation band, sutured margin and subgrain development (Fig. 12d). Intragranular or intergranular cracks are the main locus for new grains development and attest for fracture-type deformation mechanism (Fig. 12d). Essentially in the larger veins, the margins, that contain higher gold grade, show laminated internal texture (Fig. 12e). Indeed, the presence of incorporated (and repeated) slivers of the wall-rocks demonstrates incremental growth of the vein during cyclic episodes of fracturing and quartz crystallization. Smallsize veins intruded into dioritic pods show orthogonal and fibrous quartz crystallization along their margins that indicate filling of open fractures by crack-seal process (Fig. 12f). The above described aspect of the vein deformation could be interpreted as the result of the combination of fracturing, quartz crystallization and moderate crystal- plastic process, certainly developed in ductile-brittle to brittle conditions (O'Hara and Haak 1992).

OUARTZ C-AXIS PREFERRED ORIENTATION Quartz measurements within the northern portion have been realized with the same analytical conditions that in the southern belt. The five selected samples are foliation parallel quartz veins coming from Antas I (sample GI13a), Antas II (sample AII-27a and A0-27b, Fig. 14b), Antas III (sample AK, Fig. 14a) and Riacho do Carneiro target, located $15 \mathrm{~km}$ north of the Antas area (sample AS-C). All samples were found within NS trending foliation except AII-27b that is oriented EW (Fig. 14b). Large scale veins were always chosen except within Antas I where the size of the quartz vein just reaches few centimeters.

The results of the quartz $<\mathrm{c}>$ axis measurement display that only one sample presents a well-defined preferred orientation indicating a sinistrai sense of shearing (Fig. 16e). This sample, collected far from the Fazenda Maria Preta area, exhibits a strong recrystallized texture with elongated quartz grains (Fig. $12 \mathrm{~g}$ ) that is not representative of the gold-bearing quartz veins of the Antas mines. Sample GI-13c also yields an oblique girdle that could be interpreted as representative of a sinistrai shearing (Fig. 16a). For the three other samples, the quartz $<\mathrm{c}>$ axis diagrams do not show any evidence of preferred orientation (Figs. 16b, c, d), fact that is coherent with the poorly oriented textures of the samples AII-27a and AII-27b but inconsistent with the well recrystallized texture exhibited by the sample AK.

INTERPRETATION Because the mineralized quartz veins always parallel the regional foliation, they could be interpreted as syndeformational veins (Hodgson 1989). However, the lack of strong internal deformation combined with the paucity of clear preferred orientation of the quartz $\langle\mathrm{c}\rangle$ axes within the veins eliminate this solution and favour the hypothesis of a late vein emplacement during a brittle stage of the deformation. This is strongly confirmed by the occurrence of intra- and intergranular cracks within the larger quartz grains (Fig. $12 \mathrm{~d})$. The quartz growth and associated mineralizing fluids are supposed to re-use the foliation anisotropy thus explaining the surprising parallelism. The sample AS-C that present evidence for plastic deformation can be interpreted as an earlier quartz vein that have suffered the ductile deformation before being percolated by mineralizing fluids.

HYDROTHERMAL ALTERATION Intense veining, high silicification and carbonatization are the most obvious signs of high fluid circulation in the Antas area. At microscopic scale, the hydrothermalism is generally marked by the growth of quartz, carbonate, albite, sulphides (pyrite, arsenopyrite, pyrrhotite), sericite and chlorite. Tourmaline and apatite have also been identified (R.P. Xavier, per. com.). In the dacite, the quartz veinlets show a symmetric, centimeterscale, brownish halo witness for the hydrothermal alteration (Fig. 12h). The halo is symmetric when veins parallel the foliation and indented when veins are oblique. This indicates that fluid percolation was guided by the foliation planes anisotropy. The best-expressed alteration is found within the andesite in which fine grain schist levels characterized by carbonate-chlorite and subsequently sericite-chloritecarbonate mineralogy occur. Within the diorite, hydrothermal alteration is marked by a characteristic kaolinization and growth of carbonate. 

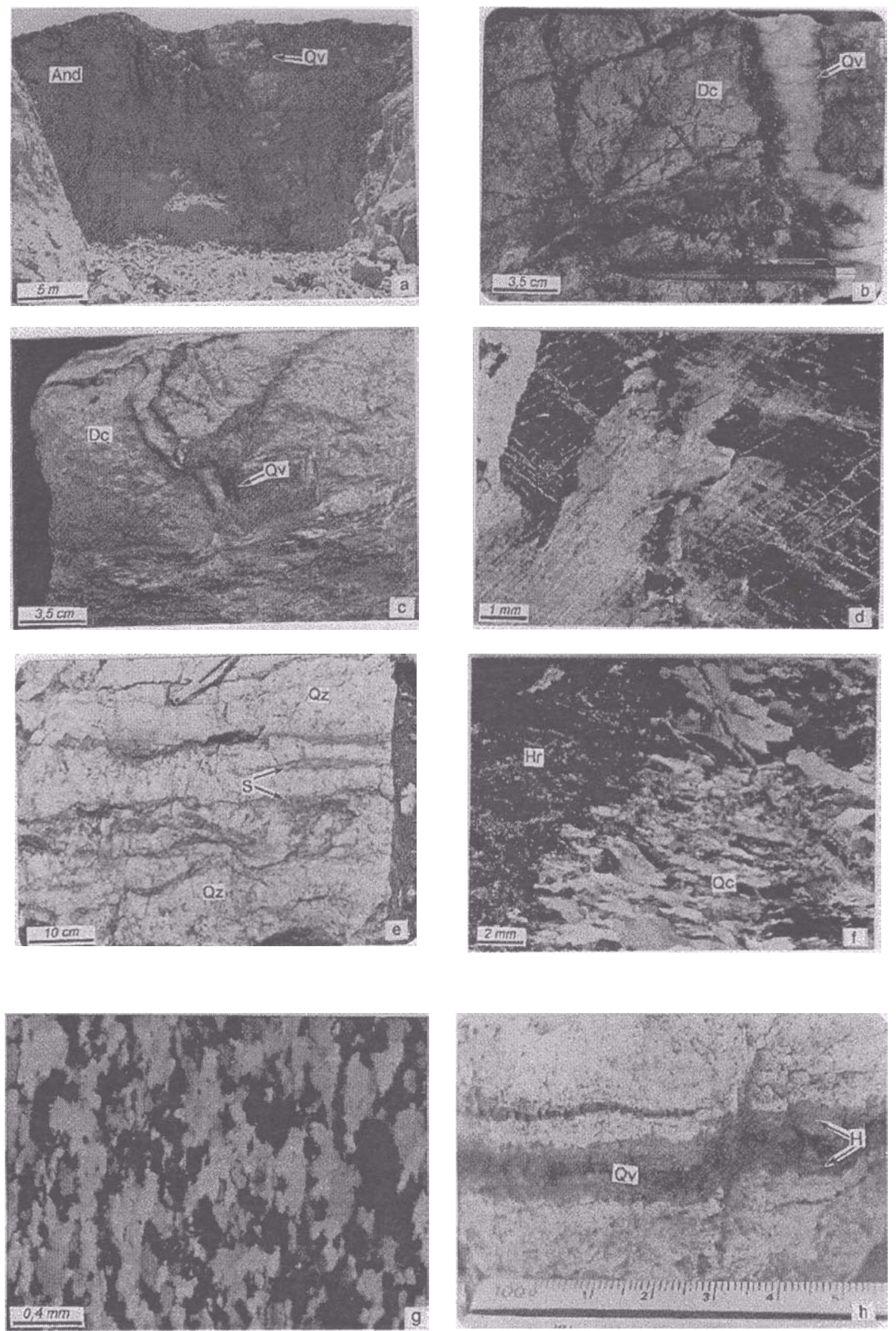

Figure 12 - Photographs of the general features of the Fazenda Maria Preta deposits, a.-View of the large-size gold-bearing quartz vein parallel to the foliation in Antas II. And = andesite, Qy-quartz vein, b, c.- Typical stockwork pattern in dacitic lithologiesfrom Antas III (b) and Antas $I$ (c) mines. $D C=$ dacite, $Q y=$ quartz vein. d.-Grain size reduction aspects from quartz vein of Antas $H$ expressed by undulose extinction, intra and inter-granular cracks and deformation bands, $e$.- View of the border of large quartz vein exhibiting sliver of the host rock, witness of multiple stages of opening, Antas II. Qz - quartz, $S=$ host rock sliver, $f$-Orthogonal and fibrous quartz crystallization along the margin of small-size veins intruded within dioriticpods, Antas III. Hr = host rock, $Q c=$ quartz crystallization, $g$. - Riacho do Carneiro quartz vein displaying completely recrystallized texture and elongated quartz grains, $h$.- Brownish alteration halo around quartz veinlets within dacite, Antas I. Di $=$ diorite, $Q y$ = quartz vein, $H=$ alteration halo. 
Semi-quantitative optic spectrographic analyses of the characteristic lithologies from both SZ-1 and SZ-2 are shown in Tab. 1. Quartz veins composition of both zones only differs by a weak occurrence of $\mathrm{Pb}$ within veins of the SZ-2. Regarding the host-rocks composition, the significant changes between the two zones are i) less $\mathrm{Mn}$ within the diorite of the SZ-1; ii) the total lack of $\mathrm{B}, \mathrm{Cu}$ and $\mathrm{Pb}$ in the andesite of the SZ-2 whereas these elements are present in the surrounding quartz vein. The implications of these chemical variations between quartz veins and surrounding lithologies on the mineralizing process will be discuss in the conclusion.

\section{ORIGIN, TIMING AND TECTONIC CONTROL OF THE AU} MINERALIZATION: A DISCUSSION Main characteristics of the RIGB gold mineralization The role played by the carbonaceous material in gold precipitation has been largely demonstrated and reported in the literature (e.g., Teagle et al. 1990). In the Rio Itapicuru gold mines, it has been clearly established in this study that carbonaceous material is always associated with the mineralization. A recent study suggests that the sulphidation of high Fe-bearing rocks (i.e., the CLX level) should be accompanied by reduction of the stability of the gold complexes thus promoted gold precipitation (Teixeira et al. 1990). However, the lack of Fe-rich lithology in the Canto mines argues against a generalization of the role played by this process in the whole RIGB. In fact, it seems that the main factor on metal concentration is the circulation of hydrothermal gold-rich fluids along preferred anisotropies represented by the ductile-brittle shear zone and the lithological contacts. A more brittle behavior of the Antas area mineralized quartz veins is observed. The importance of the ambient lithology like the existence of the CLX-GRX association
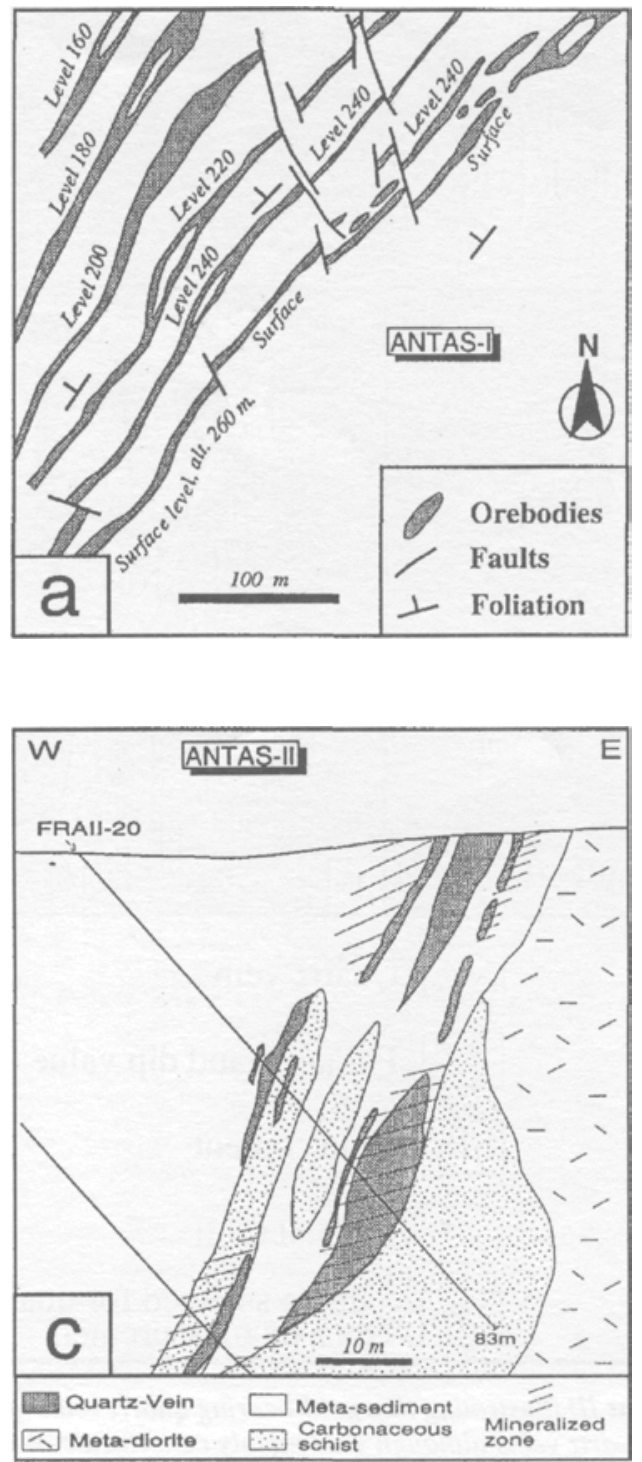

added to the opportunity to concentrate gold. This model confirms the late concentration of gold with respect to the general tectonic evolution.

Origin and timing of the mineralization Gold within the NMZ and SMZ are assumed to result from the same mineralizing event although some differences exist due to the lithological variations of the host rocks. If the economic mineralization is clearly related to late hydrothermal processes, an early syngenetic gold concentration has been suggested for the Fazenda Brasileiro deposit based on the existence of anomalous gold grades (from 0.1 to $1.0 \mathrm{ppm}$.) in un-mineralized zones of the CLX (Santos et al. 1988). A similar argument was used by Alves da Silva and Matos (1990, CVRD Company, internal report) and Silva and Rocha Netto (1993) for whom gold was originally located in the volcanic pile. A recent fluid inclusion study favours such an early syngenetic gold concentration created during a basin-related hot exhalative hydrothermal stage (Coelho 1994). Initial sea-floor hydrothermal activity forming auriferous exhalates was also invoked to account for a lot of Archean gold deposits (Hutchinson 1987).

Because gold orebodies display highly diversified host rock association, any attempts to link the genesis of important $\mathrm{Au}$ deposit to the nature of the surrounding lithology cannot be valid. Indeed, the intervention of a late stage of remobilization to account for the localized high metal concentration appears necessary. This may be an efficient mechanism that leaches gold from a great volume of rocks and precipitates it in grades of 6-8 g per ton in narrow zones. Using an average concentration of $2 \mathrm{ppb}$ in the basalts, Reinhardt and Davison (1990) estimated that leaching of $35 \mathrm{~km}^{3}$ of basalts would be necessary to explain the 110 tons of gold in Fazenda Brasileiro mine. Such volume is consistent with the surface of basalt existing between the Barrocas oluton and the Weber Belt (see Fie. 3a). The two major processes that

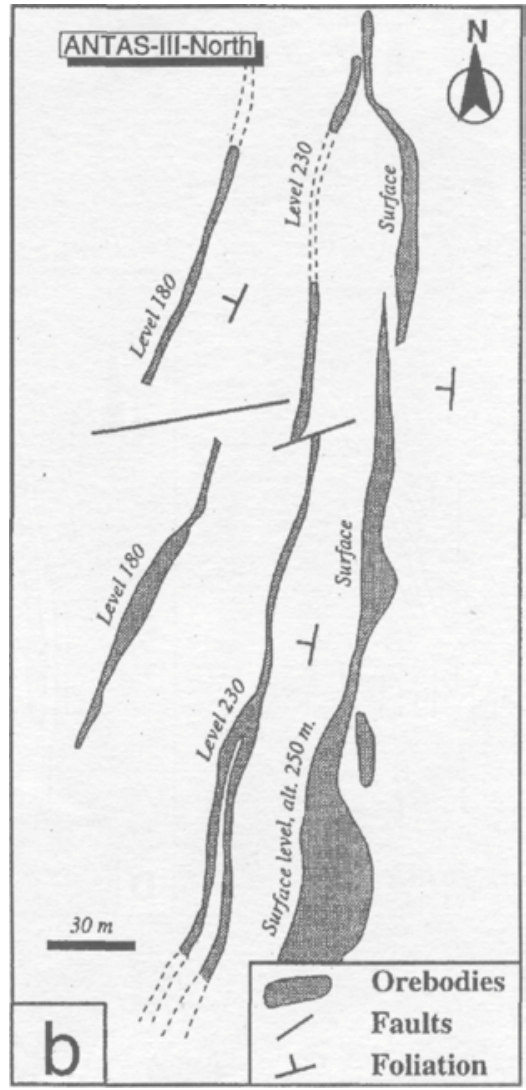

Figure 13 - Detailed structure of the Antas deposits. a.-Map arrangement of the orebodies from surface to level 160 based on 41 drilling bore holes. The number associated to the level is the altitude with respect to the sea level. Note that mineralization occurs following a plane oriented N040 and dipping westward, parallel to the general orientation of the foliation in Antas L b.- Similar for Antas III, northern portion, c.- Detailed cross-section of the Antas II mine showing Au distribution within and around quartz veins (Modified from Oliveira et al., DOCEGEO internal report). 
could explain the formation of hydrothermal fluids in order to leach and to concentrate gold within the RIGB are: magmatism and metamorphism.

MAGMATISM Granitoid emplacement largely dominates the tectonic evolution of the study area (Alves da Silva et al. 1993, Alves da Silva, 1994). The granite can provide the necessary heat for the supracrustal dehydration and thus might explain the mineralizing fluids of the RIGB (Boyle 1979, Burrow and Spooner 1989, Silva and Rocha Netto 1993). Additionally, the presence of boron in the ore (Antas area, Tab. 1), the occurrence of quartz-porphyry bodies and the existence of a late magmatic phase of tourmaline-bearing pegmatite within the Ambrósio pluton (Matos and Davison 1987), support a link between magmatism and mineralization. In the SMZ, mineralization has been considered to be contemporaneous to the Barrocas pluton emplacement (Reinhardt and Davison 1990). The geochronological data available both on the granite (Barrocas crystallization age of $2127+5 \mathrm{Ma}, \mathrm{Pb} / \mathrm{Pb}$ evaporation age on zircon, Alves da Silva 1994) and on the mineralization $\left({ }^{40} \mathrm{Ar} r^{39} \mathrm{Ar}\right.$ biotite and muscovite ages bracketed between ca. 2083 and ca. $2031 \mathrm{Ma}$, Vasconcelos and Becker 1992) do not support this hypothesis. However, the thermal event due to a large granitic intrusion could last several tens of $\mathrm{Ma}$ and the subsequent hydrothermal process can persist more than $10 \mathrm{Ma}$ (up to $54 \mathrm{Ma}$ for several gold deposits around the world: Abitibi belt and Meguna terrain, Canada; Vitoria

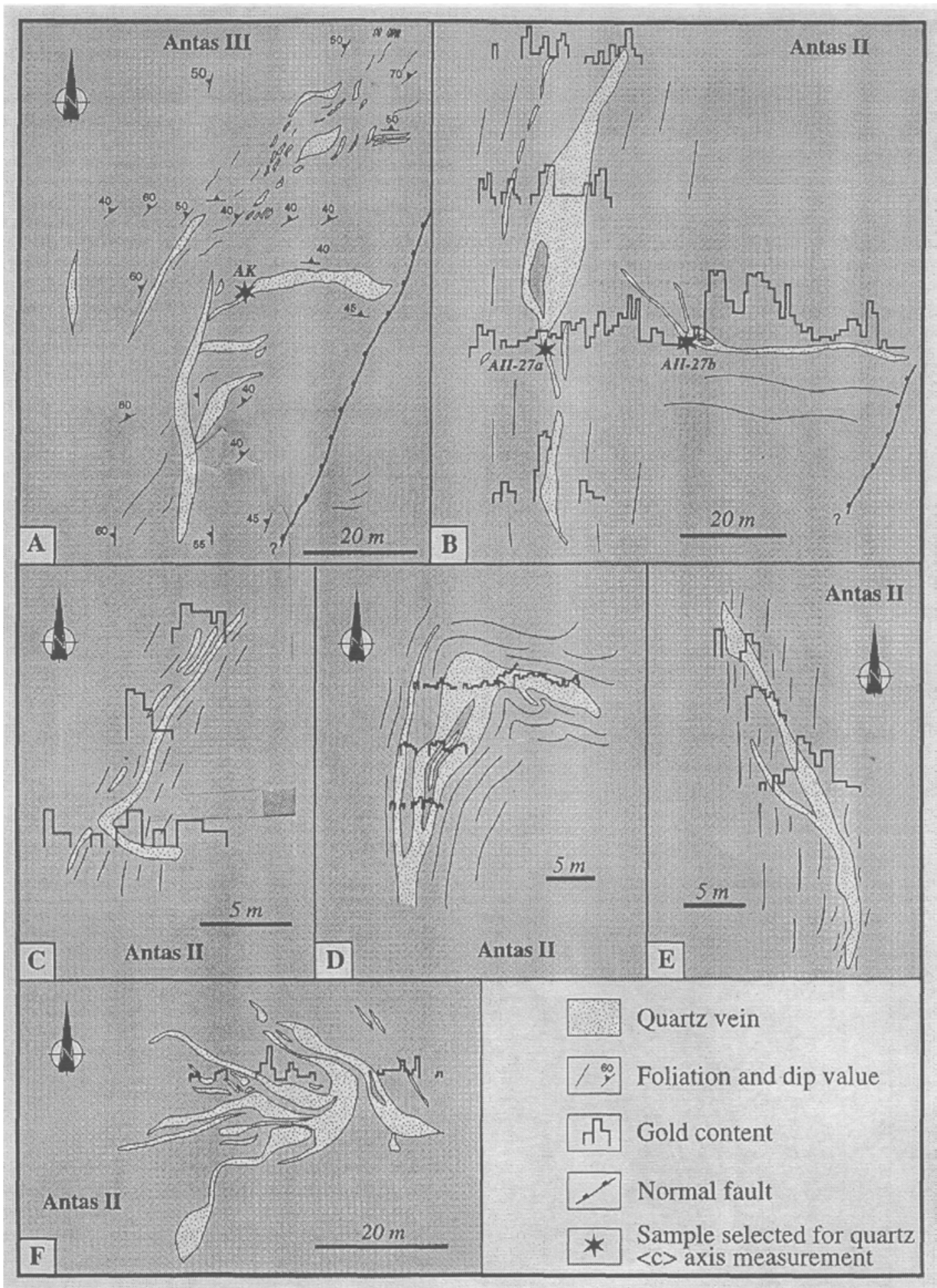

Figure 14 - Small-size mapping of the main orebodies of Antas 11 and Antas III illustrating that gold-bearing quartz veins many of them parallel the foliation. Note the close relationship between gold occurrence and quartz veins although gold mainly concentrate along the margin of the large veins (i.e., map B and D). A cut-off 0.7 and maximum of $210 \mathrm{~g}$ Au/t were used for the An content histograms. 


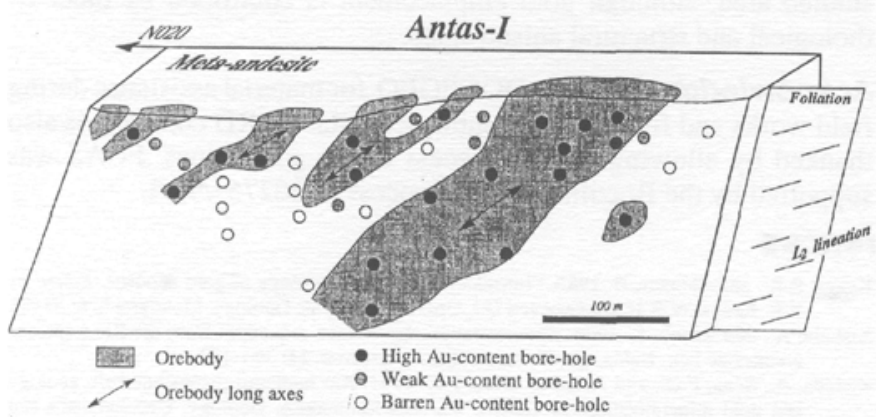

Figure 15 - Geometry of the main oreshoots within Antas I mine defined by drilling and showing a roughly-defined parallelism between oreshoot long axis and ductile stretching lineation.

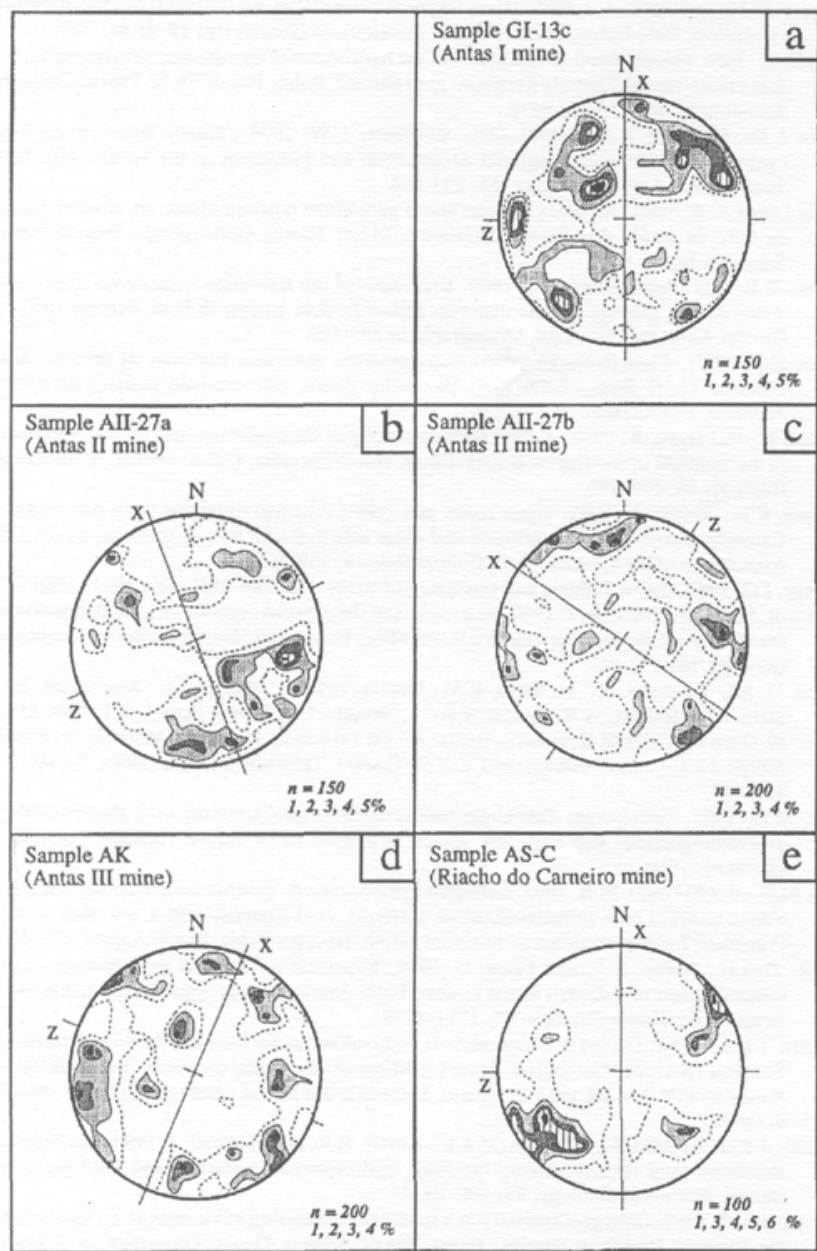

Figure 16 - Crystallographic fabrics of quartz axes for selected samples of the Fazenda Maria Preta area. Sample locations are indicated in figure 14 except for $a$ and e. Numbers of grains measured and contour values are indicated at the right beneath each Schmidt lowerhemisphere diagram. The equator line (indicator of the foliation plane) for each diagram has been oriented with respect to the north. See text for comments.

region, Australia; Mother lode, California; e.g., Miller et al. 1994 and references therein). Thus, a long-lived hydrothermal activity due to the emplacement of the Transamazonian granites around ca. $2100 \mathrm{Ma}$ could be at the origin of the gold mineralization of the RIGB. According to the radiometric dates, such an hydrothermal event may begin at ca. $2087 \mathrm{Ma}$, ca. $13 \mathrm{Ma}$ after the major phase of Transamazonian granite intrusion ( $D_{2}$ event at ca. $2100 \mathrm{Ma}$, Alves da Silva 1994), and finishes few $10 \mathrm{Ma}$ later, as illustrated by the ${ }^{40} \mathrm{Ar}{ }^{\beta 9} \mathrm{Ar}$ ages on mineralized samples (Vasconcelos and Becker, 1992).

METAMORPHISM The anomalous high background of $\mathrm{Au}$ in the volcanic rocks of the region (data got from the explorations companies
Table 1 - Semi-quantitative analysis of the different lithotypes that characterized the SZ-1 and the SZ-2 (see location in figure 11) that contain the three main gold mine of the Fazenda Maria Preta area (Antas I, II, III). Chemical analyses were realized in SUTEC-CVRD laboratories.

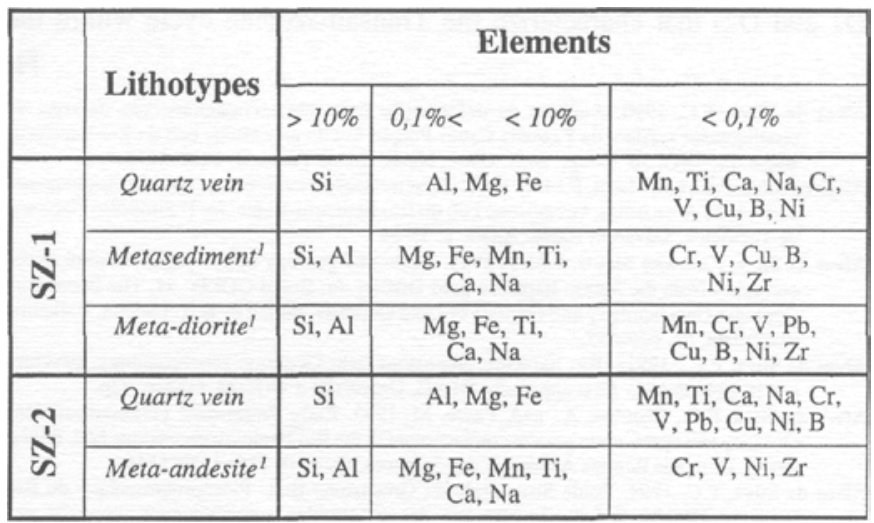

: including quartz veinlets that cannot be separated

working in the area) and the low salinity of the fluid inclusion located within mineralized quartz veins are favourable arguments for metamorphic fluid to explain the mineralizing event of the RIGB. This hypothesis is supported by recent fluid inclusion and $\mathrm{d}^{18} \mathrm{O}_{\mathrm{H} 20}$ and $\mathrm{d}^{18} \mathrm{D}_{\mathrm{H} 20}$ studies (Xavier 1993) that sugest a metamorphic origin with derived magmatic components (e.g., S and $\mathrm{CO}_{2}$ ). Thus, the metamorphic influence on the leaching process cannot be ruled out although the relative low grade of the regional metamorphism during the Transamazonian cycle does not favour this hypothesis (Silva 1987, Alves da Silva 1994)

Tectonic control A particularity of the RIGB gold deposits consists in the surprising parallelism between orebody long axis and the ductile event-related stretching lineation. This fact contrasts with the ductile-brittle/brittle features of the gold vein deformation. If such a phenomenon has been described for few gold mines (i. e. South Africa, Vearncombe et al. 1989), it does not represent the majority of case studies (i. e., the Canadian gold deposits, Poulsen and Robert 1989). This paradoxical situation involves two possibilities: gold is pre to syn deformation or gold is posterior and crystallizes following the direction of the ductile deformation features. In other words, we may question if: i) gold was precoceous, and then experienced the whole deformation history and concentrated when host rock cooled down below the temperature of $\mathrm{Au}$ deposition or ii) gold was introduced later within the system (after the fixation of all $\mathrm{CO}_{2}$, sulphur, ars'enic and potassium in the alteration halos). In the RIGB, the quartz veins and associated sulfide phases clearly overprint the mylonitic foliation (Marimon et al. 1986). Moreover, undeformed hydrothermal minerals (white mica, biotite, chlorite) are aligned along the mylonitic fabric thus suggesting that crystallization was guided by host rock anisotropy. This is confirmed by the predominance of fluid-assisted process during quartz-vein deformation. A satisfying model is that the fluids are canalized from the dilatation sites toward the shear zones, and that Au-deposition is guided by rock fabrics such as the linear anisotropy formed by the Transamazonian-related early ductile structures.

From the above, it seems that if metamorphic and magmatic sources could contribute to the RIGB mineralizing event, the influence of plutonism is predominant. The process can be divided into two stages integrated within the tectonic evolution proposed by Alves da Silva (1994). Earliest metamorphic fluids, generated during D 1 thrust event, promoted the first stage of gold leaching from the volcanic pile. Progressively, the deformation evolved from thrust style toward strikeslip one coeval with the granitoid emplacement. The switch from horizontal (D1 event) toward vertical (D2 event) tectonic style would ease fluid circulation along vertical anisotropies. The emplacement of granites largely helped fluid circulation because i) they directly created fluids of magmatic origin and ii) they provided increasing heating that dehydrated the supracrustal units and favoured leaching. During their circulation through the volcanic pile, such hot fluids will be enriched in gold and finally canalized along brittle shear zones where $\mathrm{Au}$ precipitation later occurred when the ambient temperature drops below $360-420^{\circ} \mathrm{C}$ (Keays and Skinner 1989). 
The main features of the RIGB gold mineralizations are summarized as following: 1) gold is mainly found in the arsenopyrite; 2) mineralization, always associated with carbonaceous material, are concentrated along shear zones that correspond to lithological contacts; 3 ) gold concentration process post-dates the ductile events (i.e., D1 and D2) that characterize the Transamazonian cycle within the studied area, although gold emplacement is controlled by older lithological and structural anisotropies.

Acknowledgments: To DOCEGEO for material assistance during field works and free use of unpublished data. CVRD company is also thanked by allowing the free access to the gold mines. FCAS was supported by the Brazilian CNPq, process $n^{\circ}$ 202757/90.3.

\section{References}

Alves da Silva, F.C. 1990. Análises da deformação finita em meta-aglomerado da zona de cisalhamento aurffera da Fazenda Canto-Porção Sul do greenstone belt do Rio ItapicuruBahia. In: SBG, $36^{\circ}$ Congr. Bras. Geol., Natal, Brasil. Anais, 6: 2208-2218.

Alves da Silva, F.C., and Matos, F.M.V. 1987. Caracterização c evolução da zona de cisalhamento aurífera da Área Antas, Greenstone belt do Rio Itapicuru-Bahia. In: $1^{\circ}$ Simpósio Naciona de Tectônica. Salvador, Bahia. Anais, 1: 57-59

Alves da Silva, F.C., and Matos, F.M.V. 1991. Economic geology and structural control of the orebodies from the Médio Itapicuru gold District. In: Brazil GOLD' 91, The Economic, Geology, Geochemistry and Genesis of Gold Deposits. Edited by E.A. Ladeira. Balkem. Rotterdam, pp. 629-635.

Alves da Silva, F.C. 199la. Rio Itapicuru greenstone belt: Geology, geochronology, structure and its gold mines.- First approach- DESG, Université d'Orleans, France, 72p.

Alves da Silva, F.C., Chauvel, A., and, Faure, M. 1993. Early Proterozoic (Transamazonian) Orogeny and syntectonic granite emplacement in the Rio Itapicuru greenstone belt, Bahia Brazil. Comptes Rendus Academic des Sciences, Paris, II, 316: 1139-1146.

Alves da Silva, F.C. 1994. Etude Structurale du Greenstone Belt Paleoproterozoique du Ri Itapicuru (Bahia, Brésil). Importance des granitoides syntcctoniques, controle dês mineralizations auriferes et evolution geodinamique Transamazonicnne $(-2,0 \mathrm{Ga}) \mathrm{d} u$ Craton de São Francisco. Université d'Orleans, France. Doct. Thesis, 338p.

Alves da Silva, F.C., Guerrot, C., Chauvet, A., and, Faure, M. 1995. Chronological and structural evidences for both archaic and modern-type tectonic styles within the Palacoprotcrozoic Rio Itapicuru Greenstone Belt, Brazil. In: 8th EUG, Strasbourg, France. Blackwell Scientific Publications, pp. 103.

Bernasconi, A. 1983. The Archearn terranes of central eastern Brazil: A review. Precambrian Research, 23: 107-131.

Bonnemaison, M., and Marcoux, E. 1990. Auriferous mineralization in some shear-zones: three-stage model of metallogencsis. Mincralium Deposita, 25: 96-104

Boyle, R.W. 1961. The geology, geochemistry and origin of the gold deposits of the Yellowknife district. Canadian Geological Survey Memoir, 310, 193p.

Boyle, R.W. 1979. The geology of gold and its deposits. Canada Geological Survey Bulletin, 280: $584 \mathrm{p}$.

Burrows, R.D., and Spooner, E.T.C. 1989. Relationships between Archean gold quartz vein-shear zone mineralization and igneous intrusions in the Val d'Or and Timmes area, Abitibi sub-province, Canada. In The geology of gold deposits. Edited by R.R. Keays, W.R.H Ramsay and D.I. Grove. Economic Geology, Monograph, 6: 37-53.

Card, K.D., Poulsen, K.H., and Robert, F. 1989. The Archean Superior Province of the Canadian Shield and its lode gold deposits. In The geology of gold deposits. Edited by R.R. Keays, W.R.H. Ramsay and D.I. Groves. Economic Geology, Monograph, 6:19-36

Castaing, C., Cassard, D., Gros, Y., Moisy, M., and Chabod, J.C. 1993. Role of Theological heterogeneities in vein-ore localization. Canadian Journal of Earth Sciences, 30: 113-123.

Chauvet, A., Coelho, C.E.S., Alves da Silva, F.C., Faure, M., and Touray, J.C. 1991. Ductile/brittle shear zone and gold concentration in Fazenda Maria Preta Deposit, Northeast of Rio Itapicuru greenstone belt. Bahia, Brazil. In Proceedings, Source, transport and deposition Itapicuru greenstone belt. Bahia, Brazil. In Proceedings, Source, transport and depo
of metals. Edited by M. Pagel and J. Leroy. Balkcma, Rotterdam, pp. 439-442.

Coelho, C.E. 1994. Gênese de fluidos dans lês zones déformées et minéralisées en or de Ia ceinturc de roches vertes de Rio Itapicuru (Brésil): gisements de Fazenda Brasileiro et Fazenda Maria Preta. Université d'Orleans, France. Doct. Thesis, $276 \mathrm{p}$.

Colvine, A.C. 1989. An empirical model for the formation of Archean gold deposits: Products of final cratonization of Superior Province, Canada. In The geology of gold deposits. Edited by R.R. Keays, W.R.H. Ramsay and D.I. Groves. Economic Geology, Monograph, 6 : $37-53$.

Cox, S.F., and Etheridge, M.A. 1989. Coupled grain-scale dilatancc and mass transfer during deformation at high fluid pressure: Examples from Mount Lyell, Tasmania. Journal of Structural Geology, 11: 147-162.

Drury, M.R., and Urai, J.C. 1990. Deformation-related rccrystallization process. Tcctonophysics, 172: 235-253

Eisenlohr, B.N., Groves, D., and Partington, G.A. 1989. Crustal-scalc shear zones and their significance to Archaean gold mineralization in Western Australia. Mincralium Deposita, 24: $1-8$

Fyon, J. A., Troop, D.G., Marmont, S., and MacDonald, A.J. 1989. Introduction of gold into Archean crust, Superior Province, Ontario - Coupling between mantle-initiated magmatism and lower crustal thermal maturation. In The geology of gold deposits. Edited by R.R. Keays, W.R.H. Ramsay and D.I. Groves. Economic Geology, Monograph, 6 : by $\mathrm{R} . \mathrm{R} . \mathrm{K}$
$479-490$.

Gaál, G., Teixeira, J.B.G., Silva, M.G., and Del Rey, J.M.H. 1987. New U-Pb data from granitoids, reflecting Early-Proterozoic evolution in Northeast Bahia-Brazil. In: Symposium on Granites and Associated Mineralizations. Salvador, Bahia

Gleason, G.C., Tullis, J., and Heidelbach, F. 1993. The role of dynamic recrystallizalion in the development of lattice preferred orientation in experimentally deformed quartz aggregates. Journal of Structural Geology, 15: 1145-1168.

Hirth, G., and Tullis, J. 1992. Dislocation creep regimes in quartz aggregates. Journal of Structural Geology, 14: 145-159.

Hodgson, C.J. 1989. The structure of shear related veins-type gold deposit: A Review. Ore Geology Review, 4: 231-273.

Hodgson, C.J., and Hamilton, J.V. 1989. Gold mineralization in the Abitibi belt: End-stag segment of Archean collisional tectonics? In The geology of gold deposits. Edited by R.R. Keays, W.R.H. Ramsay and D.I. Groves. Economic Geology, Monograph, 6: 86-ÍOO.

Hutchinson, R.W. 1987. Metallogeny of Precambrian gold deposits: Space and time relationships Economic Geology, 82: 1993-2007.

Inda, H.A.V., and Barbosa, F.F. 1978. Mapa geológico de estado da Bahia 1/1 000000.

Jessell, M.W. 1988. Simulation of fabric development in recrystallized aggregates- II Example model runs. Journal of Structural Geology, 10: 779-794

Jessell, M.W., and Lister, G.S. 1990. A simulation of the temperature dependence of quartz fabrics. In Deformation mechanisms, Rheology and Tectonic. Edited by R.J. Knipe and E. H. Rutter. Geological Society Special Publication, London, 54: 353-362.
Keays, R.R., and Skinner, B. 1989. "Introduction". In The geology of gold deposits. Edited by R.R. Keays, W.R.H. Ramsay and D.I. Groves. Economic Geology, Monograph, 6: 37-53. Kishida, A., and Riccio, L. 1980. Chemostratigraphy of lava sequences from the Rio Itapicuru

Kishida, A., Sena, P.O., and Alves da Silva, F.C. 1991. Rio Itapicuru greenstone belt: geology and gold mineralization. In GOLD' 91, The Economics, Geology, Geochemistry and Genesis of Gold Deposits. Edited by E.A. Ladeira. Balkema, Rotterdam, pp. 49-59.

Marimon, M.P.C., Kishida, A., and Teixeira, J.B.G. 1986. Estudo da alteração hidrotermal relacionada à mineralização aurffera na mina Fazenda Brasileiro (BA). In: SBG, $34^{\circ}$ Congr. Brás. Geol. Goiânia, Brazil. Anais 4: 1556-1570.

Matos, F.M.V., and Davison, 1.1987. Basement or intrusion? The Ambrósio Dome, Rio Itapicuru Greenstone Belt, Bahia, Brazil. Revista Brasileira de Geociências 17, 4: 442-449.

Melo Jr., G. 1990. Geochemical investigation of the hydrothermal alteration zone surrounding the greenstone-hosted Fazenda Brasileiro gold deposit, Bahia, Brazil. Ph.D. Thesis, Colorado School of Mines, U.S.A., 547p

Miller, L.D., Goldfarb, R.J., Gehrel, G.E., and Snce, L.W. 1994. Genetic links among fluid cycling, vein formation, regional deformation and plutonism in the Juneau gold belt, Southeastern Alaska. Geology, 22: 203-206.

Monte Lopes, C.A. 1982. Algumas características geológicas e geoqufmicas das mineralizaçõe de ouro da jazida da Fazenda Brasileiro. M.Sc. Thesis, Universidade Federal Bahia. Salvador, Brazil, 99p.

Nesbitt, B.E., and Muehlenhachs, K. 1989. Evidence for ore formation from evolved meteoric water. In The geology of gold deposits. Edited by R.R. Keays, W.R.H. Ramsay and D.I. Groves. Economic Geology, Monograph, 6: 553-563

Neves, H.M. 1991. Caracterização gcometrica-estrutural dos veios aurfferos da área da min Fazenda Maria Preta, Santa Luz, Ba. M.Sc thesis, Universidade Federal da Bahia. Salvador, Bahia, 1OOp.

O'Hara, K., and Haak, A. 1992. A fluid inclusion study of fluid pressure and salinity variations in the footwall of the Rector Branch thrust, North Carolina, U.S.A. Journal of Structural Geology, 14: 579-589.

Poulsen, K.H., Robert, F. 1989. Shear zones and gold / Practical examples from the southern Canadian Shield. In Mineralization and shear zones. Edited by J.T. Bursnall. Geological Association of the Canada, Short Course Notes 6: 239-266.

Ramsay, J.G. 1967. Editor Folding and fracturing of rocks. McGraw-Hill, New York, 568p.

Reinhardt, M.C., and Davison, I. 1990. Structural and lithoiogical controls on gold deposition in the shear zone-hosted Fazenda Brasileiro Mine, Bahia state, Northeast Brazil. Economic Geology, 85: 952-967.

Santos, O. M., Vitorasso, E.C.L., Silva, R.M., Guerra, H.R.M., Chaves, J.L., Mantovani, T.J., Silva, R.A., Kalil Jr., A.R., Santos, V.A.M., Navarro, L.A.G., and Pena, L.S.T. 1988 Mina Edited by C. Schobbenhaus and C.E.S. Coelho. DNPM/CVRD, Brasília, Brasil, 3 : 431-444.

Silva, M.G. 1987. Geochemie, Petrologie und tcktonishe Entwickulung eins Proterozoichen gruensteinguertels: Rio Itapicuru, Bahia, Brasilien. Ph.D Thesis, Freiburg University, Germany, $161 \mathrm{p}$

Silva, M.G., Rocha Netto, M.B. 1993. Evolução mctamórfica do greenstone belt do Rio Itapicuru c suas relações com as mineralizações aurfferas. / «:!! Simpósio sobre o Craton do São Francisco: Evolução teclônica e metalogcnética. Salvador Bahia, Brasil. Anais 1: 323-326.

Teagle, D.A.H., Norris, R.J., and Craw, D. 1990. Structural controls on gold-bearing quartz mineralization in a duplex thrust system, Hyde-Macraes shear zone, Otago schist, New Zealand. Economic Geology, 85: 1711-1719.

Teixeira J.B.G. 1985. Geologia c controles da mineralização aurífera em Fazenda Brasileiro, Scrrinha (BA). In: Geologia e Recursos Minerais do Estado da Bahia, Textos Básicos. Edited by P.V.S.V. Sá and F.B Duarte. Secretaria das Minas e Energia, Salvador, Brazil, 6: $09-49$

Teixeira, J.B.G., Kishida, A., Marimon, M.P.C., Xavier, R.P., and McReath, 1.1990. The Fazenda Brasileiro gold deposit, Bahia: Geology, hydrothermal alteration, and fluid inclusion studies. Economic Geology, 85: 990-1009. the Fazenda Brasileiro deposit, Bahia, Brazil. Master Thesis, University of Texas at Austin, U.S.A., 102p.

Vasconcelos, P., and Becker, T. 1992. A idade da mineralização aurffera no depósito da Fazenda Brasileiro, Bahia, Brasil. In: Workshop em Mctalogêncsis: Pesquisas atuais e nova tendências. Universidade de Campinas, São Paulo, Brazil. Boletim de Resumos, pp. 29

Vearncombc, J.R., Barley, M.E., Eisenhohr, B.N., Groves, D.I., Houstoun, S.M., and Skwarnecki, M.S. 1989. Structural controls on Mesothcrmal gold mineralization: Examples from the Archean Terranes of Southern Africa and Western Australia. In The geology of gold deposits. Edited by R.R. Keays, W.R.H. Ramsay and D.I. Groves. Economic Geology, Monograph, 6: 124-135.

Vitorasso, E., Chaves, J.L., Costa, C.H., Hegenberg, F.E., Magno Jr., L.B., Orlandi, P.M., Santos, V.A.M., Silva, R.A., Alves da Silva, F.C., and Matos, F.M.V. 1991. Fazenda Brasileiro gold mine - Teofilandia Bahia: General geological aspects. In: Brazil Gold' 91, The Economics, Geology, Geochemistry and Genesis of Gold Deposits. Edited by Sena F. Balkema, Rotterdam. Excursion-guide.

White, S. 1977. Geological significance of recovery and rccrystallization processes in quartz. Tectonophysics, 39: 143-177.

Xavier, R. P. 1993. Fluidos associados a depósitos de ouro mesotermais do greenstone belt do Rio Itapicuru greenstone belt, Bahia: Principais characterísticas e possíveis fontes. In Proceedings, II Simpósio sobre o Craton do São Francisco: Evolução tectônica c metalogenética. Salvador Bahia, Brazil. Anais, 1: 319-322. greenstone belt, Bahia, Brazil. Precambrian Research, 11: 161-178. de Ouro de Fazenda Brasileiro, Bahia. In: Os Principais Depósitos Minerais do Brasil.

Vasconcelos, P. 1987. Gold geochemistry in a semi-arid weathering environment: a case study of 